Review

\title{
Non-Energetic Chemical Products by Fermentation of Hydrolyzed Sewage Sludge
}

\author{
Manuel García, Paula Oulego (D), Mario Díaz and Sergio Collado *(D) \\ Department of Chemical and Environmental Engineering, University of Oviedo, E-33071 Oviedo, Spain; \\ manugarcia10@hotmail.com (M.G.); oulegopaula@uniovi.es (P.O.); mariodiaz@uniovi.es (M.D.) \\ * Correspondence: colladosergio@uniovi.es; Tel.: +34-985-10-34-43; Fax: +34-985-10-34-34
}

Citation: García, M.; Oulego, P.; Díaz, M.; Collado, S. Non-Energetic Chemical Products by Fermentation of Hydrolyzed Sewage Sludge. Sustainability 2021, 13, 5499. https://doi.org/10.3390/su13105499

Academic Editor: Farooq Sher

Received: 26 April 2021

Accepted: 7 May 2021

Published: 14 May 2021

Publisher's Note: MDPI stays neutral with regard to jurisdictional claims in published maps and institutional affiliations.

Copyright: (c) 2021 by the authors. Licensee MDPI, Basel, Switzerland. This article is an open access article distributed under the terms and conditions of the Creative Commons Attribution (CC BY) license (https:/ / creativecommons.org/licenses/by/ $4.0 /)$.

\begin{abstract}
Hydrolysis and the solubilization of sewage sludge processes are important tools to obtain small and medium molecules with different application perspectives. Although the production of biomethane and other products such as biohydrogen from sludge as biofuel alternatives has been profusely studied, the current perspectives are mainly focused on the use of the sludge hydrolysate to produce non-energy bioproducts and biomaterials. In this review, the most recent bibliography dealing with the use of sludge hydrolysates as fermentation media for the bioproduction of new non-energetic products with industrial interest is here revised and discussed. In this regard, the main research effort has been focused on the bioproduction of short-chain fatty acids due to their direct use in industrial applications or as a carbon source for polyhydroxyalkanoates-producing microorganisms. The use of sludge hydrolysates as fermentation media using pure cultures to produce more complex biomolecules, such as enzymes or lipids, is gaining interest, but it remains an undervalued topic. The literature has been divided into processes where hydrolysis and fermentation stages took place simultaneously or separately, centering them on the effect of the main operational conditions on the yields and properties of the corresponding metabolites produced. In general, the main limiting step of these kinds of processes is the proper solubilization and hydrolysis of the sludge, which can improve the bioassimilation of nutrients and, subsequently, the productivities and compositions of the metabolites obtained. Biological and/or thermal pretreaments are the options more profusely employed, which are frequently assisted by different promoters such as oxidants, surfactants, or cation exchange resins.
\end{abstract}

Keywords: sewage sludge; fermentation; hydrolysis; short chain fatty acids; polyhydroxyalkanoates

\section{Highlights}

- A growing number of new products are being proposed.

- The production of complex metabolites (enzymes or lipids) is promising but understudied.

- Hydrolysis and solubilization are critical in final product yields and profiles.

- Positive synergies by coupling thermal pretreatment and pure culture fermentation.

- Assisted biological hydrolysis is the most employed pretreatment.

\section{Introduction}

Wastewater treatment plants (WWTPs) are mainly responsible for decontaminating wastewaters resulting from human activities. As a consequence of this depuration process, huge amounts of sewage sludge, ranging from 3.1 to $8.2 \mathrm{~L}$ per inhabitant and day, are generated [1]. As a reference to provide an idea of how much sludge is generated, more than 10 million tons of sludge are expected to be produced in 2020 only in the EU, on the basis of the statistical data collected in recent years [2]. These large quantities of sludge require a proper management, since this waste comprises microorganisms and suspended and colloidal matter, thus involving potential hazards, due to the presence of, among other 
pollutants, heavy metals or pathogens, such as viruses [3]. In fact, the management of this sludge usually comprises between $20 \%$ and $60 \%$ of the operational costs in a WWTP [1].

The traditional uses for sewage sludge have included land application (with or without previous composting), landfilling, or energy recovery. Nevertheless, the following should be noted: (i) land application has to compete with other waste streams, the demand is variable and the legislation about this topic is becoming increasingly strict, (ii) landfilling is an unsustainable outlet due to concerns over pollution, loss of recyclable materials, and loss of void for those wastes which cannot be recycled, and (iii) incineration is a high cost/high technology option and is currently only likely to be cost-effective for large cities, and it does not have a high level of public acceptability due to concerns over gas emissions [4]. Another sludge management strategy commonly used in the WWTPs is the anaerobic digestion, that is to say, the sludge self-digestion to produce biogas $[5,6]$. However, the intermediate steps of this process require long times and well-controlled conditions.

As can be seen, conventional sludge management strategies are only focused on stabilizing the sludge and reducing its volume, obtaining low value energy products at its best. In this sense, some more recent alternatives include the conversion of the sludge into bio-oils and biochars from pyrolysis; biofuels, syngas, and chemicals from gasification as well as recovering minerals such as struvite $[7,8]$. Nevertheless, analyzing the sludge composition, these approaches clearly underestimate its potential. As previously indicated, sludge is composed by microorganisms and dissolved organic matter. Therefore, focusing on its biochemical composition, sludge comprises a complex mixture of proteins, carbohydrates, and lipids, an important proportion of humic substances, nutrients, and minerals [9-11]. Hence, sludge is now emerging as a renewable source for biomolecules with a higher added value than biogas or compost. This approach will allow putting WWTPs into the circular economy context, by taking advantage of a waste that it is currently underused. In a long term and with adequate treatments, WWTPs will be turned into bio-factories, where wastes will be minimized in favor of obtaining green feedstocks [12-14], thus matching the objectives recently proposed by the EU in its New Circular Economy Action Plan [15].

It is interesting to note that many of the either conventional or new strategies for sludge valorization require an initial pretreatment to solubilize the biomolecules from the microorganisms or the sludge flocs [16]. With the objective of achieving an appropriate sludge disruption, different technologies have been applied, including either biological, thermal, chemical, physical or biochemical treatments. Although this is a well-documented field, a brief review of these technologies will be here carried out in order to put into perspective their different hydrolysis mechanisms.

The most employed hydrolysis treatment may be the biological one. In this method, the own sludge microorganisms are responsible for the reactions that break cells and extracellular polymeric substances (EPS) structures via enzymatic reactions [17]. The second method for sludge solubilization is the thermal one, which is based in the supply of heat to the cells to achieve protein denaturation and membrane disintegration, provoking the cytoplasmatic content release. Usually, thermal methods also involve high pressures to raise the water boiling point, thus allowing higher temperatures. These methods are known as hydrothermal ones. A modification of these is also possible by introducing in the mixture an oxidant, being the process defined as wet oxidation. The particularity of these processes lies on the reactivity of the oxygen at high temperatures, being able to enhance the solubilization, although it can also transform the molecules structure by the generation of carboxyl, carbonyl, hydroxyl, and other functional groups that include oxygen in their structure [18].

On the other hand, chemical methods are based on the addition of reagents that could alter different parameters of the environment to achieve either EPS structure or membrane integrity disruption as well as both of them. This is the case of ozone, surfactants, or other reagents $\left(\mathrm{Ca}(\mathrm{OH})_{2}, \mathrm{CaO}, \mathrm{NaOH} \ldots\right.$... $)[19,20]$. Physical methods employ shear forces to achieve the cell breakage, thus releasing their inner contents. These shear forces can be 
generated from several sources: homogenizers, mills, pressure jets, or ultrasounds [21,22]. Finally, biochemical treatments, including the use of hydrolytic enzymes such as proteases, cellulases, or amylases, which are also capable of destroying the sludge structure, solubilizing the EPS and, if an adequate enzyme cocktail is employed, destroying the cell wall as well $[9,23]$.

Once the sludge has been hydrolyzed and the target molecules have been solubilized, the first approach that can be made is their direct recovery from the hydrolysate in a more or less pure form to exploit their commercial value. In this way, the recovered proteins can be used in the formulation of coatings, biofilms, adhesives, surfactants, or organic fertilizers [24-28]. Humic acids also have commercial value, being used as fertilizers or surfactants [29]. Lipids can be employed as feedstock for biodiesel production [30]. The phosphorus present in the sludge has been already recovered as struvite as previously commented. With this aim, several approaches have been made, although results were not as promising as to unseat the conventional treatment methods, since low recoveries or low purified streams were usually obtained [31-34]. Then, more research in this field is required to develop better strategies with higher recoveries and purities for further green uses of these biopolymers.

Other approaches that are being deeply studied and that also fulfill the circular economy goal involve the use of these sludge hydrolysates as fermentation media for the bioproduction of different metabolites with industrial interest. In this regard, depending on the hydrolysis method employed, the hydrolysate will show different characteristics that will make them more suitable for the bioproduction of certain products with respect to others. When it comes to choosing a hydrolysate as fermentation medium, by revising the products obtained from the fermentation of sludge hydrolysates, it can be concluded that the cornerstone is the content of short-chain fatty acids (SCFAs) in the hydrolysates. Therefore, a little reclassification of the hydrolysis methods has to be done. The only change is the separation of extreme versions of oxidative hydrothermal treatments (long times and severe temperature and pressure conditions), which can also be carried out to produce effluents with a high proportion of SCFAs, thus emulating the sludge hydrolysates obtained by biological processes $[35,36]$. Figure 1 shows a scheme of the different hydrolysis methods, the main characteristics of the hydrolysate and the final products that could be obtained with each treatment, in order to improve the understanding of which hydrolysate is supposed to be better for its use as substrate for subsequent fermentations.

As explained, biological hydrolysis is carried out by microorganisms. However, these microorganisms hydrolyze the sludge to use it as substrate and in consequence, they transform the biomolecules present in the sludge into SCFAs. Since both hydrolysis and acidogenic processes are almost simultaneous, it is very difficult to separate them. This is the reason why biological fermentation of the sludge yields a high content of SCFAs, such as acetic acid, propionic acid, etc., than other hydrolysis processes [37,38]. Therefore, this kind of hydrolysates would be useful as substrate for fermentations in which the fermentative microorganisms need a readily assimilable carbon source, for instance, in polyhydroxyalkanoates (PHAs) or lipids production [39-41].

Moving on to the hydrolysates obtained from thermal treatments, these will be composed by proteins, lipids, carbohydrates, and humic substances as well as cell debris and nutrients, such as ammonium or phosphorus [10,42,43]. Therefore, they will show high chemical oxygen demand (COD) contents due to the solubilization of organics such as proteins and carbohydrates, but low SCFAs concentration [44]. This composition is suitable for its use as a fermentation medium for producing high molecular weight products such as enzymes. Obviously, hydrolysates obtained after a hydrothermal treatment can also be employed as substrate for a further biological fermentation to produce SCFAs, which can be subsequently recovered or used as substrate for PHAs production. As mentioned, the extreme versions of the oxidative thermal treatments lead to high SCFAs production and would be adequate for sludges containing high proportions of humic substances or other molecules toxic or recalcitrant to biological degradation [45]. The hydrolysates 
thus obtained can be employed in the same processes as those generated by biological hydrolysis.

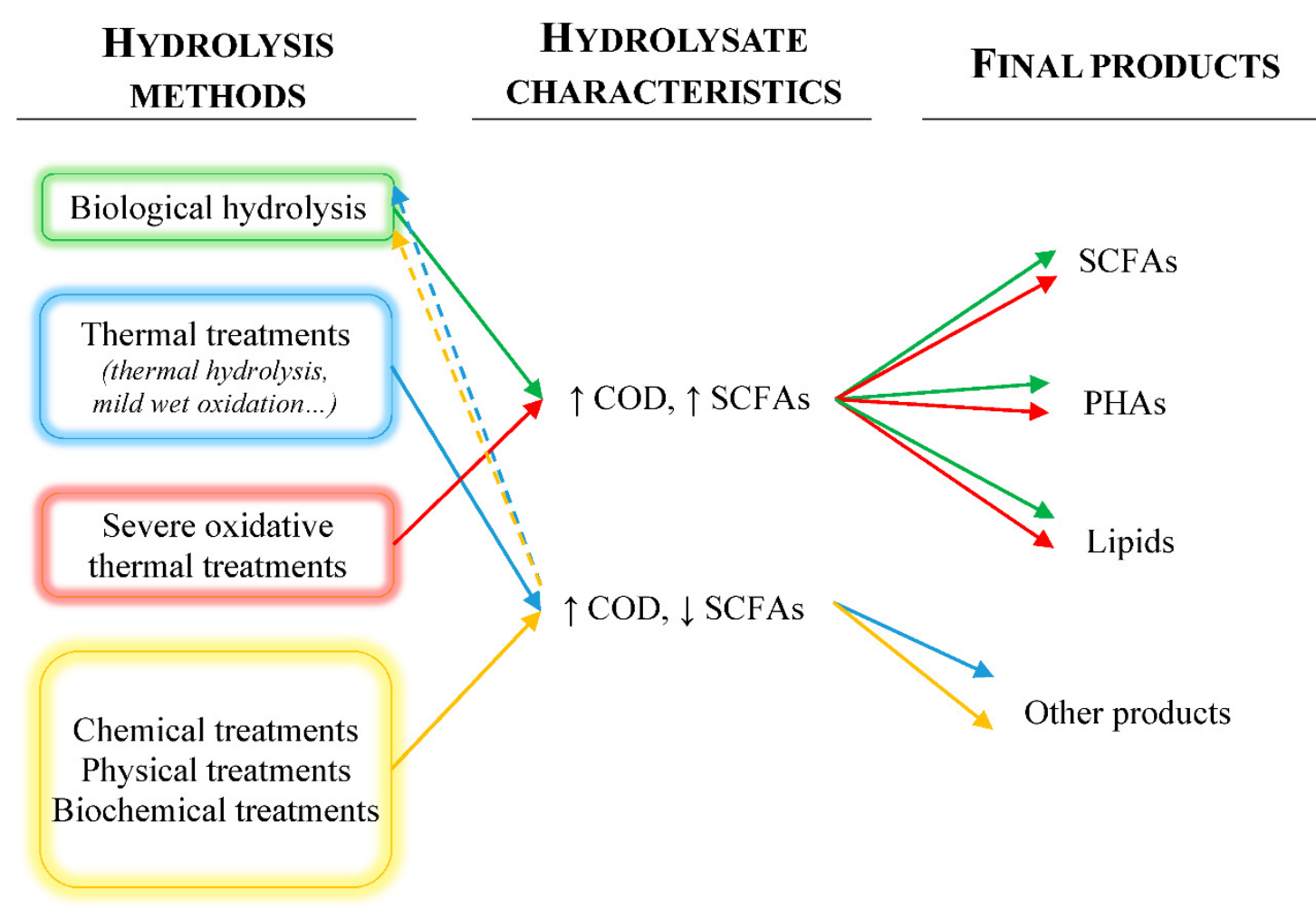

Figure 1. Main hydrolysis methods for sludge, hydrolysate characteristics, and potential final products. Dashed lines indicate the application of the previous hydrolysis method as pretreatment for the method to which they lead.

Separately, chemical, physical, and biochemical hydrolysis methods will produce hydrolysates similar to those obtained by thermal methods, which can be employed in the same applications to those mentioned before $[9,46]$. At this point, it must be highlighted that the combination of different hydrolysis methods is feasible and can generate some positive synergies. Many examples of these combinations will be seen in the following sections by studying particular cases.

Therefore, the aim of this review is to recompile and discuss the most recent literature dealing with the use of sludge hydrolysates as fermentation substrates to obtain different bioproducts and the potential applications of these, paying special attention to the effect of the main operational conditions on yields. Previously, studies were divided into processes where hydrolysis and fermentation stage took place simultaneous or separately.

It should be stressed that among the products that can be obtained by fermentation of sludge hydrolysates, the production of either biogas or biohydrogen has already been extensively studied in the bibliography; excellent reviews about these topics exist in the literature [5,47-51]. As a result, the bioproduction of these metabolites has not been included in this work, which is more focused on more innovative products.

\section{Short-Chain Fatty Acids}

\subsection{General Considerations}

New approaches focused on the sludge anaerobic digestion as fermentative alternative to produce short-chain fatty acids (SCFAs), and not biogas, have gained a heightened interest in the last few years. This strategy, based on stopping the anaerobic digestion at the end of the acidification step and before the acetogenic one, could balance the economics of a WWTP due to the production and accumulation in the sludge hydrolysate of SCFAs such as acetic, propionic, or butyric ones [38]. 
The worth of the SCFAs underlies in their commercial applications even if they are not in their pure forms. The potential uses of these molecules have already been extensively reviewed and they will be here cited very briefly [52-56]. These include their employment as substrates to obtain different products or electricity by fermentation as well as nutrient removal in the WWTP. After purification steps, their potential applications comprise food industry, as preservatives; the cosmetic industry; and pharmaceuticals. The economical aspects regarding SCFAs productions can be found in the literature $[57,58]$.

In recent times, SCFAs production from sludge hydrolysates has attracted some attention with several reviews [46,59-61]. In this review, only the most recently published articles were included, discussing the effect of the main operational conditions on the production and composition of SCFAs generated. These have been summarized in Table 1.

\subsection{Simultaneous Hydrolysis and Fermentation}

\subsubsection{Biological Hydrolysis without Additives}

Effect of $\mathrm{pH}$

Several authors have concluded that $\mathrm{pH}$ plays a key role during the direct fermentation of sludge to produce SCFAs. In this sense, Li et al. [62] studied the alkaline fermentation, at $\mathrm{pH} 10$ and $35^{\circ} \mathrm{C}$, of a settled secondary sludge in a semi-continuous process.

Although results for sludge fermentation at the same conditions but without $\mathrm{pH}$ adjustment were not provided, this strategy at $\mathrm{pH} 10$ allowed a high sludge solubilization, with final soluble COD (SCOD) at the end of each cycle two times higher than the initial one. The production of SCFAs was also significant at $\mathrm{pH} 10$, with a maximum value of approximately $610 \mathrm{mg}$ COD/g VSS (VSS stands for volatile suspended solids) for a sludge retention time (SRT) of 8 days. However, for higher SRT, SCFAs concentration began to slowly decrease, which was probably due to the substrate depletion and the methanogenic activity. Focusing on the SCFAs composition, acetic acid was the overwhelming acid during the whole anaerobic fermentation time, accounting for about $84 \%$ of SCFAs, followed by propionic, which accounted for approximately $11 \%$. Iso-butyric, n-butyric, iso-valeric, and $\mathrm{n}$-valeric acids were also detected, but at very low concentrations: $1.2 \%, 0.7 \%, 2.7 \%$, and $0.1 \%$, respectively. These authors also reported the predominance of Clostridium, Bacillus, Amphibacillus, and Peptostreptococcaceae in the microbiota during the alkaline fermentation of sludge.

A deeper study about the $\mathrm{pH}$ effect during the sludge fermentation on SCFAs production was carried out by Ma et al. [63], who studied the acidogenic fermentation and characterized the dissolved organic matter (DOM) under different alkaline $\mathrm{pH}$ values. For this purpose, a secondary sludge was subjected to a set of fermentations in a semicontinuous mode, at $37^{\circ} \mathrm{C}$ for 80 days, with a hydraulic retention time (HRT) of 8 days and an organic load rate (OLR) of $1.49 \mathrm{~g} \mathrm{VS} \mathrm{L}^{-1} \mathrm{~d}^{-1}$, under different controlled $\mathrm{pH}$, ranging from 7 to 10 between experiments. Additionally, another fermentation was conducted at the same conditions but without $\mathrm{pH}$ control as reference.

Results revealed that the higher the $\mathrm{pH}$, the higher the sludge solubilization. As an example, SCOD for fermentation at $\mathrm{pH} 10$ was 53.73 times higher than under uncontrolled $\mathrm{pH}$, whereas this value was clearly lower for less alkaline media (11.69 times for $\mathrm{pH}=7$ ). In parallel, soluble protein concentration at alkaline $\mathrm{pH}$ values was significantly higher than that at uncontrolled $\mathrm{pH}$ or 7 , whereas soluble polysaccharide increased slightly with the increase in $\mathrm{pH}$, but its content was always lower than the content of solubilized protein in all the reactors. This intense solubilization at alkaline $\mathrm{pH}$ also led to a higher accumulation of SCFAs, increasing productions from $1315 \mathrm{mg} \mathrm{COD/L}$, for uncontrolled $\mathrm{pH}$, to $3762 \mathrm{mg}$ $\mathrm{COD} / \mathrm{L}$ at $\mathrm{pH} 10$.

Nevertheless, $\mathrm{pH}$ had a low impact on the SCFAs/SCOD ratio, which slightly enhanced from 0.51 without $\mathrm{pH}$ adjustment to 0.58 at $\mathrm{pH} 10$. To assess these findings, authors studied DOM evolution during the fermentations at each $\mathrm{pH}$ value, discovering that in spite of solubilizing more intensely, alkaline $\mathrm{pHs}$ led to higher accumulation of refractory compounds, such as humic substances and lignin-like compounds. 
Finally, although these authors reported an increase in the concentrations of acetic, propionic, butyric, iso-butyric, valeric, and iso-valeric acids, the proportion of each acid did not change significantly with $\mathrm{pH}$. Thus, the SCFAs profile at $\mathrm{pH} 10$ was dominated by acetic acid $(44.7 \%)$, followed by propionic acid $(17.1 \%)$, iso-valeric acid $(15.8 \%)$, iso-butyric acid $(10.5 \%)$, n-butyric acid $(9.2 \%)$, and, finally, $n$-valeric acid $(2.6 \%)$. This SCFAs profile was slightly different to the obtained during the fermentation at uncontrolled $\mathrm{pH}$, being the percentages for the same sequence of acids $46.2 \%, 26.9 \%, 9.6 \%, 7.7 \%, 3.8 \%$, and $5.8 \%$. Therefore, it can be observed that an increase in the $\mathrm{pH}$ value during the fermentation led to a slight increase in iso-valeric and n-butyric acid proportions at the expense of a reduction in the corresponding to propionic acid.

Continuing with the alkaline fermentation of sludge, Yan et al. [64] also investigated the performance of SCFAs production by anaerobic digestion for 111 days under mesophilic conditions $\left(35-40{ }^{\circ} \mathrm{C}\right)$ with stepwise $\mathrm{pH}$ increases from 8 to 11 but employing a sludge previously dosed with poly-aluminum chloride. The results showed that either the SCOD concentration or SCFAs production increased gradually with increasing $\mathrm{pH}$, with a maximum yield of SCFAs of $358.03 \mathrm{mg}$ COD/g VS (volatile solid) at $\mathrm{pH} 11$. Thus, SCOD/SCOD and SCFAs/SCOD ratios ranged from 0.51 for $\mathrm{pH} 8$ to 0.68 for $\mathrm{pH} 11$, respectively.

As in the previous studies, acetic and propionic acids were the main SCFAs for all the $\mathrm{pH}$ tested, whereas butyric and valeric acids were detected and accumulated at $\mathrm{pH}$ of 10 and 11. Specifically, at $\mathrm{pH} 11$, acetic acid predominated (39.6\%) followed by iso-valeric acid $(16 \%)$, propionic acid $(13.9 \%)$, n-butyric acid $(11.1 \%)$, iso-butyric acid $(10.4 \%)$, and, finally, $\mathrm{n}$-valeric acid ( $9 \%)$. On the other hand, only acetic and propionic acid were present at $\mathrm{pH}$ 8 , being their percentages of $30 \%$ and $70 \%$, respectively. According to Yan et al. [64], these changes in the SCFAs distribution were related to the solubilization degree, since when more proteins were present, a higher proportion of butyric and valeric acids (and their iso forms) were synthesized by the microorganisms.

Finally, an attempt to better understand the $\mathrm{pH}$ control on the acidogenic fermentation was made by Chen et al. [65], who evaluated sludge fermentations under different $\mathrm{pH}$ control strategies: without $\mathrm{pH}$ control, only fitting initial $\mathrm{pH}$ to 10 , or keeping the $\mathrm{pH}$ constant at a value of 10 during the whole process. Their feedstock was a settled secondary sludge, carrying out batch fermentations at room temperature for 16 days without using especial inoculum or acclimation steps. Results revealed that fermentation at controlled $\mathrm{pH} 10$ yielded the highest solubilization $\left(\mathrm{SCOD} / \mathrm{SCOD}_{\mathrm{o}}=9.43\right)$ and SCFAs accumulation, $3080 \mathrm{mg}$ COD/L, which represented the $50.2 \%$ of the SCOD, after 15 days. On the other hand, when only initial $\mathrm{pH}$ was fitted to 10, the maximum SCFAs concentration was reduced to $1750 \mathrm{mg}$ COD/L after 10 days, whereas SCFAs/SCOD was 0.58 and $\mathrm{SCOD} / \mathrm{SCOD}_{\mathrm{o}}$ was 4.62 . As can be seen, when the $\mathrm{pH}$ was only initially adjusted to $\mathrm{pH}$ 10 relative to when the $\mathrm{pH}$ was continuously maintained at 10 , the purity of SCFAs in the fermented liquid was improved. In addition, initial $\mathrm{pH} 10$ fermentation also improved the phosphorous removal efficiency, and fermented sludge dewaterability during waste activated sludge (WAS) fermentation.

Regrettably, no information about SCFAs composition was given in this work, although, as seen in the previous studies, it is expectable that the different strategies provided different SCFAs profiles. 
Table 1. Summary of the main parameters of the studies dealing with SCFAs production. "-" indicates data not available or unable to be calculated.

\begin{tabular}{|c|c|c|c|c|c|c|c|c|c|c|c|}
\hline \multirow{4}{*}{$\begin{array}{c}\text { Settled secondary } \\
\left(\mathrm{VSS}_{\mathrm{o}}=15.8 \mathrm{~g} / \mathrm{L}\right) \\
\left(\mathrm{TCOD}_{\mathrm{o}}=26.56 \mathrm{~g} / \mathrm{L}\right) \\
\left(\mathrm{SCOD}_{\mathrm{o}}=3.73 \mathrm{~g} / \mathrm{L}\right)\end{array}$} & \multirow[t]{4}{*}{$\begin{array}{l}\text { Conditions for } \\
\text { Pretreatment }\end{array}$} & \multirow[t]{4}{*}{ Pretreatment Results } & \multirow{4}{*}{$\begin{array}{c}\begin{array}{c}\text { Conditions for Biological Hydrolysis } \\
\text { (Anaerobic in All Cases) }\end{array} \\
\text { Reactor: expanded granular sludge blanket reactor } \\
\text { Acclimation at } 35^{\circ} \mathrm{C} \text { and } \mathrm{pH} 100 \text { two stages of } 8 \text { days each } \\
\text { one, at } 8 \text { th and } 16 \text { th day } 2 / 3 \text { of sludge were replaced at } \mathrm{pH} 10 \\
\text { (after } 16 \text { th day, steady state was reached) } \\
\text { Semi-continuous operation at } 35^{\circ} \mathrm{C} \text { and } \mathrm{pH} 10,5 \text { cycles of } 20 \\
\text { days each. After each cycle, } 2 / 3 \text { of volume was replaced with } \\
\text { fresh sludge }\end{array}$} & \multirow{2}{*}{\multicolumn{7}{|c|}{$\begin{array}{c}\begin{array}{c}\text { Fermentation Results } \\
\text { (Best Results Were Those with Higher SCFAs } \\
\text { Concentration) }\end{array} \\
{\left[\mathrm{SCFAs}_{\mathrm{MAX}}\right] \approx 610 \mathrm{mg} \mathrm{COD} / \mathrm{g} \mathrm{VSS}(8 \mathrm{~d} \text { of } 2 \text { nd cycle })} \\
\mathrm{SCFAs} \mathrm{MAX}_{\mathrm{MAC}} / \mathrm{SCOD}=- \\
\mathrm{SCOD} / \mathrm{SCOD}_{\mathrm{o}} \approx 2.1 \text { for each cycle }\end{array}$}} & References \\
\hline & & & & & & & & & & & \multirow{3}{*}{ Li et al. 2018} \\
\hline & & & & \multirow[t]{2}{*}{$\begin{array}{l}\text { Acid } \\
(\%)\end{array}$} & Ac. & Pr. & $\begin{array}{l}\text { n- } \\
\text { bu. }\end{array}$ & $\begin{array}{l}\text { i- } \\
\text { bu. }\end{array}$ & $\begin{array}{l}\text { i- } \\
\text { va. }\end{array}$ & $\begin{array}{l}\mathrm{n}- \\
\text { va. }\end{array}$ & \\
\hline & & & & & 84 & 11.3 & 0.7 & 1.2 & 2.7 & 0.1 & \\
\hline \multirow{3}{*}{$\begin{array}{l}\text { Clarified secondary } \\
\left(\mathrm{VSS}_{\mathrm{o}}=11.91 \mathrm{~g} / \mathrm{L}\right) \\
\left(\mathrm{TCOD}_{\mathrm{o}}=17.98 \mathrm{~g} / \mathrm{L}\right) \\
\left(\mathrm{SCOD}_{\mathrm{o}}=0.12 \mathrm{~g} / \mathrm{L}\right)\end{array}$} & & & \multirow{3}{*}{$\begin{array}{c}\text { Reactor: semi-continuous mixed at } 37^{\circ} \mathrm{C} \text { for } 80 \text { days } \\
5 \mathrm{pHs}=\text { uncontrolled, } 7,8,9 \text { and } 10 \\
\text { No acclimation } \\
\text { Equal parts of inoculum and feedstock } \\
0.05 \mathrm{~L} \text { replaced daily } \rightarrow \mathrm{HRT}=8 \mathrm{~d} \text {, OLR }=1.49 \mathrm{~g} \mathrm{VS} \mathrm{L}^{-1} \mathrm{~d}^{-1}\end{array}$} & \multicolumn{7}{|c|}{$\begin{array}{c}\text { Best results at } \mathrm{pH} 10 \\
{[\mathrm{SCFAs} \text { MAX] }=3762 \mathrm{mg} \mathrm{COD} / \mathrm{L} \text { (from } 10 \text { days) }} \\
\mathrm{SCFAs}_{\mathrm{MAX}} / \mathrm{SCOD}=0.58 \text { (from } 10 \text { days) } \\
\mathrm{SCOD} / \mathrm{SCOD}_{\mathrm{o}}=53.73 \text { (from } 10 \text { days) }\end{array}$} & \multirow{3}{*}{ Ma et al. 2019} \\
\hline & & & & \multirow{2}{*}{$\begin{array}{l}\text { Acid } \\
(\%)\end{array}$} & Ac. & Pr. & $\begin{array}{l}\text { n- } \\
\text { bu. }\end{array}$ & $\begin{array}{l}\text { i- } \\
\text { bu. }\end{array}$ & $\begin{array}{l}\text { i- } \\
\text { va. }\end{array}$ & $\begin{array}{l}\mathrm{n}- \\
\text { va. }\end{array}$ & \\
\hline & & & & & 44.7 & 17.1 & 9.2 & 10.5 & 15.8 & 2.6 & \\
\hline \multirow{3}{*}{$\begin{array}{l}\text { Settled secondary with } \\
\text { poly-aluminum } \\
\text { chloride } \\
\left(\mathrm{VS}_{\mathrm{o}}=12.01 \mathrm{~g} / \mathrm{L}\right) \\
\left(\mathrm{TCOD}_{\mathrm{o}}=13.29 \mathrm{~g} / \mathrm{L}\right) \\
\left(\mathrm{SCOD}_{\mathrm{o}}=0.05 \mathrm{~g} / \mathrm{L}\right)\end{array}$} & & & \multirow{3}{*}{$\begin{array}{l}\text { Reactor: semi-continuous mixed at } 35-40^{\circ} \mathrm{C} \text { for } 111 \text { days } \\
\mathrm{pH}(8 \text { to } 11) \text { incremented in } 1 \text { unit after, at least, } 2 \mathrm{SRTs} \\
\text { No acclimation } \\
0.1 \mathrm{~L} \text { replaced daily } \rightarrow \text { SRT }=8 \mathrm{~d} \text {, OLR }=1.33 \mathrm{~g} \mathrm{COD} \mathrm{L}^{-1} \mathrm{~d}^{-1}\end{array}$} & \multicolumn{7}{|c|}{ 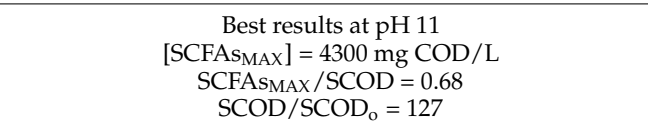 } & \multirow{3}{*}{ Yan et al. 2021} \\
\hline & & & & \multirow[t]{2}{*}{$\begin{array}{l}\text { Acid } \\
(\%)\end{array}$} & Ac. & Pr. & $\begin{array}{l}\mathrm{n}- \\
\text { bu. }\end{array}$ & $\begin{array}{l}\text { i- } \\
\text { bu. }\end{array}$ & $\begin{array}{l}\text { i- } \\
\text { va. }\end{array}$ & $\begin{array}{l}\mathrm{n}- \\
\text { va. }\end{array}$ & \\
\hline & & & & & 39.6 & 13.9 & 11.1 & 10.4 & 16 & 9 & \\
\hline $\begin{array}{c}\text { Settled secondary } \\
\left(\mathrm{VS}_{\mathrm{o}}=12.83 \mathrm{~g} / \mathrm{L}\right) \\
\left(\mathrm{TCOD}_{\mathrm{o}}=23.87 \mathrm{~g} / \mathrm{L}\right) \\
\left(\mathrm{SCOD}_{\mathrm{o}}=0.65 \mathrm{~g} / \mathrm{L}\right)\end{array}$ & & & $\begin{array}{c}\text { Reactor: CSR batch at room temperature for } 16 \text { days } \\
3 \mathrm{pH} \text { scenario: free } \mathrm{pH} \text {, initial } \mathrm{pH}=10 \text {, initial and daily } \mathrm{pH} \\
\text { adjustment to } 10 \\
\text { No acclimation }\end{array}$ & \multicolumn{7}{|c|}{$\begin{array}{l}\text { Best results at initial and daily } \mathrm{pH} \text { adjustment to } 10 \\
\text { [SCFAs } \\
\text { SCFAX }=3080 \mathrm{mg} \text { COD } / \mathrm{L} \text { (15 days) } \\
\text { SCAsAX } / \mathrm{SCOD}=0.5 \text { ( } 15 \text { days }) \\
\left.\text { SCOD } / \mathrm{SCOD}_{\mathrm{o}}=9.43 \text { (15 days }\right)\end{array}$} & $\begin{array}{l}\text { Chen et al. } \\
2021\end{array}$ \\
\hline \multirow{4}{*}{$\begin{array}{l}\text { Settled secondary } \\
\left(\mathrm{VSS}_{\mathrm{o}}=13.21 \mathrm{~g} / \mathrm{L}\right) \\
\left(\mathrm{TCOD}_{\mathrm{o}}=17.11 \mathrm{~g} / \mathrm{L}\right) \\
\left(\mathrm{SCOD}_{\mathrm{o}} \approx 0.25 \mathrm{~g} / \mathrm{L}\right)\end{array}$} & & & \multirow{4}{*}{$\begin{array}{l}\text { Reactor: } \mathrm{CSR} \text { batch at } 35^{\circ} \mathrm{C}, 12 \text { days } \\
\text { CER dosages of } 0 \text { (control), } 1,1.75,3.5 \mathrm{~g} \text { dry weight/g SS } \\
\text { pH neither controlled nor monitored }\end{array}$} & \multicolumn{7}{|c|}{ 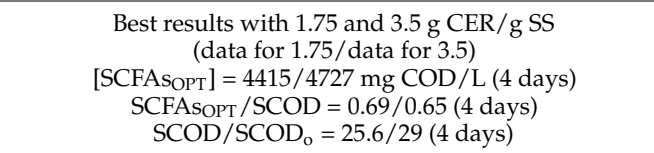 } & \multirow{4}{*}{$\begin{array}{l}\text { Pang et al. } \\
2020\end{array}$} \\
\hline & & & & $\begin{array}{l}\text { Acid } \\
(\%)\end{array}$ & Ac. & Pr. & $\begin{array}{c}\mathrm{n}- \\
\mathrm{bu} .\end{array}$ & $\begin{array}{c}\mathrm{i}- \\
\mathrm{bu} .\end{array}$ & $\begin{array}{c}\mathrm{i}- \\
\text { va. }\end{array}$ & $\begin{array}{l}\text { n- } \\
\text { va. }\end{array}$ & \\
\hline & & & & $\begin{array}{c}1.75 \mathrm{~g} \\
\text { CER/g SS }\end{array}$ & 37.5 & 20 & 15 & 7.5 & 15 & 5 & \\
\hline & & & & $\begin{array}{c}3.5 \mathrm{~g} \\
\mathrm{CER} / \mathrm{g} S \mathrm{SS}\end{array}$ & 40 & 17.5 & 14 & 8.5 & 15 & 5 & \\
\hline
\end{tabular}


Table 1. Cont

\begin{tabular}{|c|c|c|c|c|c|c|c|c|c|}
\hline Sludge & $\begin{array}{l}\text { Conditions for } \\
\text { Pretreatment }\end{array}$ & Pretreatment Results & $\begin{array}{l}\text { Conditions for Biological Hydrolysis } \\
\text { (Anaerobic in All Cases) }\end{array}$ & (Bes & $\begin{aligned} F \\
\text { Results }\end{aligned}$ & $\begin{array}{l}\text { rmentation Res } \\
\text { Vere Those witl } \\
\text { Concentration }\end{array}$ & Higher SCFAs & & References \\
\hline \multirow{4}{*}{$\begin{array}{l}\text { Settled secondary } \\
\left(\mathrm{VSS}_{\mathrm{o}}=12.2 \mathrm{~g} / \mathrm{L}\right) \\
\left(\mathrm{TCOD}_{\mathrm{o}}=16.7 \mathrm{~g} / \mathrm{L}\right) \\
\left(\mathrm{SCOD}_{\mathrm{o}}=0.26 \mathrm{~g} / \mathrm{L}\right)\end{array}$} & & & \multirow{4}{*}{$\begin{array}{c}\text { Reactor: batch at } 35^{\circ} \mathrm{C} \\
\text { Different CER dosages, stirring intensities and fermentation } \\
\text { times according to a CCD } \\
\text { pH neither controlled nor monitored }\end{array}$} & & & Optimal result & & & \multirow{4}{*}{$\begin{array}{l}\text { Pang et al. } \\
\quad 2021\end{array}$} \\
\hline & & & & $\begin{array}{c}\text { CER } \\
(\mathrm{g} / \mathrm{g} \mathrm{SS})\end{array}$ & $\begin{array}{l}\text { Time } \\
\text { (d) }\end{array}$ & $\begin{array}{l}\text { Stirring } \underset{\text { D }}{D D_{M}} \\
(\mathrm{rpm}) \\
(\%)\end{array}$ & $\begin{array}{ll}\text { SCFAs } & \text { CER } \\
(\mathrm{mg} & (\mathrm{g} / \mathrm{g} \\
\mathrm{COD} / \mathrm{L}) \mathrm{SS})\end{array}$ & $\begin{array}{l}\text { Time } \\
\text { (d) }\end{array}$ & \\
\hline & & & & 2.05 & 4.97 & 246.9 & $4351.5 \quad 2.05$ & 4.97 & \\
\hline & & & & 1.78 & 6.46 & $261.2 \quad 42.8$ & $\begin{array}{ll}4570.5 & 1.78\end{array}$ & 6.46 & \\
\hline \multirow{3}{*}{$\begin{array}{c}\text { Waste activated } \\
\left(\mathrm{VSS}_{\mathrm{o}}=9.96 \mathrm{~g} / \mathrm{L}\right) \\
\left(\mathrm{TCOD}_{\mathrm{o}}=13.45 \mathrm{~g} / \mathrm{L}\right) \\
\left(\mathrm{SCOD}_{\mathrm{o}}=0.15 \mathrm{~g} / \mathrm{L}\right)\end{array}$} & & & \multirow{3}{*}{$\begin{array}{l}\text { Reactor: CSR batch at } 37^{\circ} \mathrm{C}, 14 \text { days } \\
\text { Sand dosages to achieve VSS/TSS ratios of } 45 \%, 50 \% \text { and } 55 \% \\
\text { (TSSo adjusted to } 15 \mathrm{~g} / \mathrm{L} \text { by diluting with tap water) and } \\
\text { control without sand (VSS/TSS ratio of } 63.1 \% \text { ) } \\
\text { Initial pH adjusted to } 10\end{array}$} & \multicolumn{5}{|c|}{$\begin{array}{c}{\left[\mathrm{SCFAs}_{\mathrm{MAX}}\right]=3002 \mathrm{mg} \mathrm{COD} / \mathrm{L}(6 \text { days })} \\
\mathrm{SCFAs}_{\mathrm{MAX}} / \mathrm{SCOD}=- \\
\mathrm{SCOD} / \mathrm{SCOD}_{\mathrm{o}}=-\end{array}$} & \multirow{3}{*}{$\begin{array}{l}\text { Jiang et al. } \\
\quad 2021\end{array}$} \\
\hline & & & & \multirow{2}{*}{$\begin{array}{c}\text { Acid } \\
(\%)\end{array}$} & Ac. & Pr. & Bu. & Val. & \\
\hline & & & & & 58.1 & 13.3 & 10.2 & 18.4 & \\
\hline \multirow{3}{*}{$\begin{array}{c}\text { Settled secondary } \\
\left(\mathrm{VSS}_{\mathrm{o}}=8.63 \mathrm{~g} / \mathrm{L}\right) \\
\left(\mathrm{TCOD}_{\mathrm{o}}=17.33 \mathrm{~g} / \mathrm{L}\right) \\
\left(\mathrm{SCOD}_{\mathrm{o}}=0.26 \mathrm{~g} / \mathrm{L}\right)\end{array}$} & & & \multirow{3}{*}{$\begin{array}{c}\text { Reactor: CSR batch at } 35^{\circ} \mathrm{C} \\
\text { No acclimation } \\
\text { Fermentation at } 35^{\circ} \mathrm{C} \text { with Fe powder, persulfate (PS), } \mathrm{Fe}+ \\
\mathrm{PS} \text { and control for } 12 \text { days } \\
\mathrm{pH} \text { no controlled }\end{array}$} & \multicolumn{4}{|c|}{$\begin{array}{c}\text { Best results with } \mathrm{Fe}+\mathrm{PS} \\
{[\mathrm{SCFAs} \text { MAX] } \approx 2255 \mathrm{mg} \mathrm{COD} / \mathrm{L}(8 \text { days })} \\
\mathrm{SCFAs} \text { MAX } / \mathrm{SCOD}=- \\
\mathrm{SCOD} / \mathrm{SCOD}_{\mathrm{o}}=-\end{array}$} & & \multirow[t]{3}{*}{ Luo et al. 2019} \\
\hline & & & & \multirow{2}{*}{$\begin{array}{c}\text { Acid } \\
(\%)\end{array}$} & Ac. & Pr. & $\mathrm{Bu}$. & Val. & \\
\hline & & & & & 76.9 & 9.7 & 5.3 & 8.1 & \\
\hline \multirow{3}{*}{$\begin{array}{c}\text { Settled secondary } \\
\left(\mathrm{VSS}_{\mathrm{o}}=10.95 \mathrm{~g} / \mathrm{L}\right) \\
\left(\mathrm{TCOD}_{\mathrm{o}}=2.67 \mathrm{~g} / \mathrm{L}\right) \\
\left(\mathrm{SCOD}_{\mathrm{o}}=-\right)\end{array}$} & & & \multirow{3}{*}{ 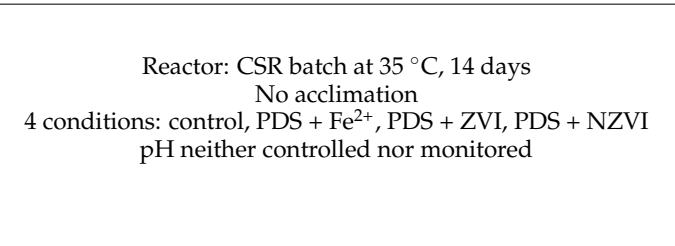 } & \multicolumn{5}{|c|}{$\begin{array}{c}\text { Best results with PDS }+\mathrm{Fe}^{2+} \\
{\left[\mathrm{SCFAs}_{\mathrm{MAX}}\right]=5537 \mathrm{mg} \mathrm{COD} / \mathrm{L}(10 \text { days })} \\
\mathrm{SCFAs}_{\mathrm{MAX}} / \mathrm{SCOD}=- \\
\mathrm{SCOD}_{\mathrm{SCOD}}=-\end{array}$} & \multirow[t]{3}{*}{ Luo et al. 2020} \\
\hline & & & & \multirow[t]{2}{*}{$\begin{array}{c}\text { Acid } \\
(\%)\end{array}$} & Ac. & $\begin{array}{c}\mathrm{n}- \\
\mathrm{bu}\end{array}$ & $\begin{array}{cc}\mathrm{i}- & \mathrm{i}- \\
\text { bu. } & \text { va. }\end{array}$ & $\begin{array}{c}\text { n- } \\
\text { va. }\end{array}$ & \\
\hline & & & & & 59.6 & 11.4 & 11.4 & 3.7 & \\
\hline \multirow{3}{*}{$\begin{array}{c}\text { Waste activated } \\
\left(\mathrm{VS}_{\mathrm{o}}=7.97 \mathrm{~g} / \mathrm{L}\right) \\
\left(\mathrm{TCOD}_{\mathrm{o}}=-\right) \\
\left(\mathrm{SCOD}_{\mathrm{o}}=0.08 \mathrm{~g} / \mathrm{L}\right)\end{array}$} & \multirow{3}{*}{$\begin{array}{l}\mathrm{CaO} \text { for } 15 \mathrm{~h} \text { at } \\
\text { different dosages: } \\
0,0.01,0.03,0.05 \\
\text { and } 0.07 \mathrm{~g} / \mathrm{g} \text { TS } \\
\left(\mathrm{TS}_{\mathrm{o}}=17.39 \mathrm{~g} / \mathrm{L}\right)\end{array}$} & \multirow{3}{*}{$\begin{array}{c}\text { Best solubilization } \\
0.07 \mathrm{~g} \mathrm{CaO} / \mathrm{g} \text { TS } \\
\mathrm{SCOD} / \mathrm{SCOD}_{\mathrm{o}}= \\
15.14 \\
\mathrm{SCOD} / \mathrm{TCOD}=- \\
\mathrm{VS} / \mathrm{VS}_{\mathrm{o}}=-\end{array}$} & \multirow{3}{*}{$\begin{array}{l}\text { Reactor: semi-continuous at } 35^{\circ} \mathrm{C}, 12 \text { days } \\
\text { HRT }=16.7 \text { by replacing } 0.06 \mathrm{~L} \text { daily } \\
\text { Inoculum ratio } 2: 1 \text { (sludge: inoculum) } \\
\text { pH neither controlled nor monitored } \\
\text { Feeding with sludge pretreated with } 0.07 \mathrm{~g} \mathrm{CaO} / \mathrm{g} \text { TS }\end{array}$} & \multicolumn{5}{|c|}{$\begin{array}{c}{\left[\mathrm{SCFAs}_{\mathrm{MAX}}\right]=2611 \mathrm{mg} \mathrm{COD} / \mathrm{L}(6 \text { days })} \\
\mathrm{SCFAs}_{\mathrm{MAX}} / \mathrm{SCOD}=- \\
\mathrm{SCOD} / \mathrm{SCOD}_{\mathrm{o}}=-\end{array}$} & \multirow{3}{*}{ Xin et al. 2021} \\
\hline & & & & $\begin{array}{c}\text { Acid } \\
(\%)\end{array}$ & Ac. & $\begin{array}{l}\mathrm{n}- \\
\mathrm{bu}\end{array}$ & $\begin{array}{l}\mathrm{i}- \\
\text { bu. }\end{array}$ & $\begin{array}{c}\text { n- } \\
\text { va. } \\
\end{array}$ & \\
\hline & & & & & 28 & 32 & 15 & 5 & \\
\hline
\end{tabular}


Table 1. Cont

\begin{tabular}{|c|c|c|c|c|c|c|c|c|c|c|c|}
\hline Sludge & $\begin{array}{l}\text { Conditions for } \\
\text { Pretreatment }\end{array}$ & Pretreatment Results & $\begin{array}{l}\text { Conditions for Biological Hydrolysis } \\
\text { (Anaerobic in All Cases) }\end{array}$ & (Best & $\begin{array}{r}\mathrm{Fe} \\
\text { esults } V\end{array}$ & $\begin{array}{l}\text { ment. } \\
\text { Jere T } \\
\text { Conce }\end{array}$ & $\begin{array}{l}\text { on } R \\
\text { se w } \\
\text { tratio }\end{array}$ & $\begin{array}{l}\text { lits } \\
\text { High }\end{array}$ & SCFA & & References \\
\hline \multirow{7}{*}{$\begin{array}{c}\text { Sewage sludge } \\
\left(\mathrm{VSS}_{\mathrm{o}}=38.42 \mathrm{~g} / \mathrm{L}\right) \\
\left(\mathrm{TCOD}_{\mathrm{o}}=79.49 \mathrm{~g} / \mathrm{L}\right) \\
\left(\mathrm{SCOD}_{\mathrm{o}}=17.02 \mathrm{~g} / \mathrm{L}\right)\end{array}$} & \multirow{7}{*}{$\begin{array}{c}\text { Autoclaving at } \\
120^{\circ} \mathrm{C}, 2 \text { bar, } 15 \\
\text { min }\end{array}$} & \multirow{7}{*}{$\begin{array}{c}\mathrm{SCOD} / \mathrm{SCOD}_{\mathrm{o}}=1.16 \\
\mathrm{SCOD} / \mathrm{TCOD}^{=}=0.26 \\
\mathrm{VSS} / \mathrm{VSS}_{\mathrm{o}}=1.1\end{array}$} & \multirow{7}{*}{ 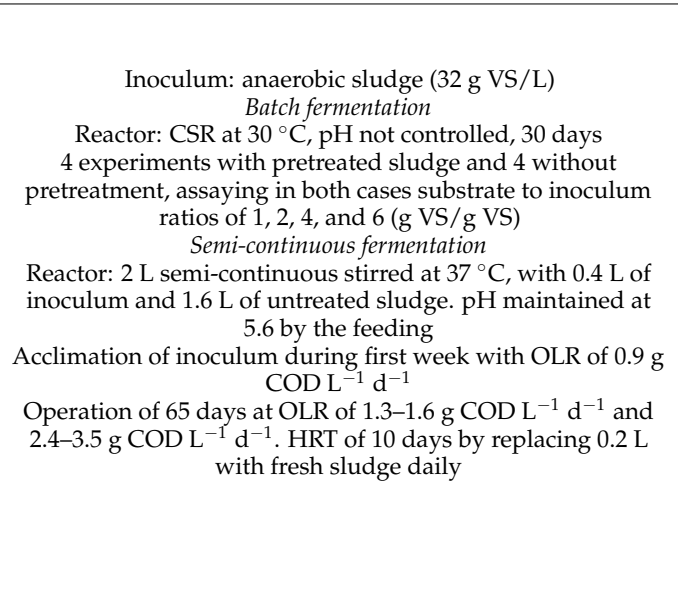 } & \multicolumn{7}{|c|}{$\begin{array}{c}\text { Batch fermentation } \\
\text { Best results at } \mathrm{S} / \mathrm{I}=6 \text { with or without pretreatment } \\
{\left[\mathrm{SCFAs} \mathrm{S}_{\mathrm{MAX}}\right] \approx 9500 \mathrm{mg} \mathrm{COD} / \mathrm{L}(\approx 17 \mathrm{~d})} \\
\mathrm{SCFAs}_{\mathrm{MAX}} / \mathrm{SCOD}=- \\
\mathrm{SCOD} \mathrm{SCOD} \mathrm{S}_{\mathrm{o}}=-\end{array}$} & \multirow{7}{*}{$\begin{array}{l}\text { Iglesias- } \\
\text { Iglesias et al. } \\
2019\end{array}$} \\
\hline & & & & Acid & Ac. & Pr. & $\begin{array}{l}\mathrm{n}- \\
\text { bu. }\end{array}$ & $\begin{array}{l}\text { i- } \\
\text { bu. }\end{array}$ & $\begin{array}{l}\mathrm{i}- \\
\text { va. }\end{array}$ & $\begin{array}{l}\mathrm{n}- \\
\text { va. }\end{array}$ & \\
\hline & & & & $\begin{array}{c}\text { Untreat. } \\
(\%)\end{array}$ & 48 & 18 & 15 & 5 & 7 & 7 & \\
\hline & & & & Treat. (\%) & 39 & 23 & 19 & 3 & 9 & 7 & \\
\hline & & & & SCFAs & $\begin{array}{r}\text { Semi- } \\
\text { Bes } \\
\mathrm{Ax} \approx 650 \\
\mathrm{SC}\end{array}$ & $\begin{array}{l}\text { ontin } \\
\text { result } \\
\mathrm{mg} \mathrm{C} \\
\mathrm{FAs} \\
\mathrm{COD}\end{array}$ & $\begin{array}{l}\text { is fer } \\
\text { at hig } \\
\text { o/L } \\
\text { /SCC } \\
\text { COD }\end{array}$ & $\begin{array}{l}\text { Itation } \\
\text { OLR } \\
7 \mathrm{~d} \text { at } \\
=- \\
-\end{array}$ & igh OL & & \\
\hline & & & & \multirow[t]{2}{*}{$\begin{array}{c}\text { Acid } \\
(\%)\end{array}$} & Ac. & Pr. & $\begin{array}{l}\mathrm{n}- \\
\text { bu. }\end{array}$ & $\begin{array}{l}\text { i- } \\
\text { bu. }\end{array}$ & $\begin{array}{c}\text { i- } \\
\text { va. }\end{array}$ & $\begin{array}{l}\mathrm{n}- \\
\text { va. }\end{array}$ & \\
\hline & & & & & 36 & 17 & 21 & 5 & 11 & 10 & \\
\hline \multirow{6}{*}{$\begin{array}{c}\text { Settled secondary } \\
\left(\mathrm{VS}_{\mathrm{o}}=8.06 \mathrm{~g} / \mathrm{L}\right) \\
\left(\mathrm{TCOD}_{\mathrm{o}}=11.67 \mathrm{~g} / \mathrm{L}\right) \\
\left(\mathrm{SCOD}_{\mathrm{o}}=0.08 \mathrm{~g} / \mathrm{L}\right)\end{array}$} & \multirow{6}{*}{$\begin{array}{l}\text { Thermal } \\
\text { pretreatment } \\
70^{\circ} \mathrm{C} \text { for } 1 \mathrm{~h} \\
\text { Chemical } \\
\text { pretreatment } \\
\text { SDBS dosage of } \\
0.01 \mathrm{~g} / \mathrm{g} \text { TS for } 1 \mathrm{~h} \\
\text { at } 20^{\circ} \mathrm{C} \\
\text { Chemical }+ \text { thermal } \\
\text { pretreatment } \\
\text { Different SDBS } \\
\text { dosages of } 0.005 \text {, } \\
0.01 \text { and } 0.02 \mathrm{~g} / \mathrm{g} \\
\mathrm{TS} \text { for } 1 \mathrm{~h} \text { at } 70^{\circ} \mathrm{C} \\
\mathrm{TS}_{\mathrm{o}}=12.41 \mathrm{~g} / \mathrm{L}\end{array}$} & \multirow{6}{*}{$\begin{array}{c}\mathrm{SCOD} / \mathrm{SCOD}_{\mathrm{o}}=24 \\
\mathrm{SCOD} / \mathrm{TCOD}=- \\
\mathrm{VSS} / \mathrm{VSS}_{\mathrm{o}}=- \\
\mathrm{SCOD} / \mathrm{SCOD}_{\mathrm{o}}=3.3 \\
\mathrm{SCOD} / \mathrm{TCOD}^{2}=- \\
\mathrm{VSS} / \mathrm{VSS} \mathrm{o}_{\mathrm{o}}=- \\
(\mathrm{SDBS}=0.01 \mathrm{~g} / \mathrm{gS}) \\
\mathrm{SCOD} / \mathrm{SCOD}_{\mathrm{o}}=28.7 \\
\mathrm{SCOD} / \mathrm{TCOD}^{2}=- \\
\mathrm{VSS} / \mathrm{VSS}_{\mathrm{o}}=-\end{array}$} & \multirow{6}{*}{$\begin{array}{l}\text { Reactor: CSR batch at } 37^{\circ} \mathrm{C}, 7 \text { days } \\
\text { pH not controlled but monitored }\end{array}$} & \multicolumn{7}{|c|}{$\begin{array}{l}\text { Results for SDBS }=0.01 \mathrm{~g} / \mathrm{g} \text { TS } \\
\left.\mathrm{CFAs}_{\mathrm{MAX}}\right]=187 \mathrm{mg} \text { COD } / \mathrm{g} \text { VS }(6 \mathrm{~d} \\
\text { SCFAs } \mathrm{MAX} / \mathrm{SCOD}=- \\
\text { SCOD } / \mathrm{SCOD}_{\mathrm{O}}=-\end{array}$} & \multirow{6}{*}{$\begin{array}{l}\text { Wan et al. } \\
2020\end{array}$} \\
\hline & & & & \multirow[t]{2}{*}{$\begin{array}{c}\text { Acid } \\
(\%)\end{array}$} & Ac. & Pr. & $\begin{array}{l}\mathrm{n}- \\
\text { bu. }\end{array}$ & $\begin{array}{l}\text { i- } \\
\text { bu. }\end{array}$ & $\begin{array}{c}\text { i- } \\
\text { va. }\end{array}$ & $\begin{array}{l}\text { n- } \\
\text { va. }\end{array}$ & \\
\hline & & & & & 39.4 & 18.6 & 7 & 10 & 21 & 4 & \\
\hline & & & & \multicolumn{7}{|c|}{$\begin{array}{c}\text { Best results with } 70^{\circ} \mathrm{C}+\mathrm{SDBS}=0.01 \mathrm{~g} / \mathrm{g} \text { TS }\left[\mathrm{SCFAs}_{\mathrm{MAX}}\right] \\
=320 \mathrm{mg} \mathrm{COD} / \mathrm{g} \mathrm{VS}(4 \text { days }) \\
\mathrm{SCFAs} \mathrm{s}_{\mathrm{MAX}} / \mathrm{SCOD}=- \\
\mathrm{SCOD} / \mathrm{SCOD}_{\mathrm{o}}=-\end{array}$} & \\
\hline & & & & \multirow[t]{2}{*}{$\begin{array}{c}\text { Acid } \\
(\%)\end{array}$} & Ac. & Pr. & $\begin{array}{l}\mathrm{n}- \\
\text { bu. }\end{array}$ & $\begin{array}{l}\text { i- } \\
\text { bu. }\end{array}$ & $\begin{array}{l}\text { i- } \\
\text { va. }\end{array}$ & $\begin{array}{l}\mathrm{n}- \\
\text { va. }\end{array}$ & \\
\hline & & & & & 56.4 & 13.6 & 10 & 6 & 9 & 5 & \\
\hline
\end{tabular}


As can be seen, all authors coincided in stating that a strongly alkaline biological hydrolysis led to higher solubilization as well as the release of compounds refractory to biological transformation. Moreover, increasing the $\mathrm{pH}$ provoked a decrease in propionic acid proportion but favored the butyric and valeric acids ones in the SCFAs profiles.

\section{Effect of OLR}

Although less studied than $\mathrm{pH}$, the organic load rate (OLR) is another operational condition with a high impact on the acidogenic fermentation. Iglesias-Iglesias et al. [66] performed a continuous lab-scale experiment at $37^{\circ} \mathrm{C}$ and without $\mathrm{pH}$ control to study the OLR effect, from 1300 to $3500 \mathrm{mg} \mathrm{COD} \mathrm{L}^{-1} \mathrm{~d}^{-1}$, on the SCFAs production. The authors observed the greatest SCFAs accumulations occurred at the highest OLR, achieving a maximum value of $0.65 \mathrm{~g} \mathrm{SCFAs}_{\mathrm{COD}} \mathrm{L}^{-1} \mathrm{~d}^{-1}$ for an OLR of $3500 \mathrm{mg} \mathrm{COD} \mathrm{L}^{-1} \mathrm{~d}^{-1}$ but not the best SCFA/SCOD ratio (18\%). This latter was found at a low OLR, $1600 \mathrm{~g}$ COD $\mathrm{L}^{-1} \mathrm{~d}^{-1}$, with a value of $22 \%$. Nevertheless, the SCFAs content at this OLR, $0.35 \mathrm{~g}$ SCFAs COD $\mathrm{L}^{-1} \mathrm{~d}^{-1}$, was distinctly lower than for $3500 \mathrm{mg} \mathrm{COD} \mathrm{L}^{-1} \mathrm{~d}^{-1}$. The authors attributed this fact to the overload of the substrate as well as to the accumulation of heavy metals and other inhibitory compounds at high OLR. The SCFAs profile was dominated by acetic, propionic, butyric, and iso-valeric acids for all the OLR tests, although it was reported that butyric and n-valeric acids proportion increased with the OLR.

\section{Effect of Inoculum Size}

Although an inoculum is not required to start the anaerobic digestion of sludge, its use can boost the process and even modify the SCFAs profile obtained. This finding was reported by Iglesias-Iglesias et al. [66], who carried out the acidogenic batch fermentation of sewage sludge at different substrate/inoculum ratios (S/I, from 1 to $6 \mathrm{~g}$ VS substrate/g VS inoculum). The inoculum used was collected from an anaerobic digester in a brewery WWTP. The authors reported that all the fermentations started immediately after the inoculation, and once the maximum SCFAs concentration was reached, its value remained almost constant. Results revealed that the higher the inoculum size, the lower the SCFAs accumulation, which ranged from $6450 \mathrm{mg} \mathrm{COD}_{\mathrm{SCFAs}} / \mathrm{L}$ for a S/I $=6$ to $2000 \mathrm{mg} \mathrm{COD}_{\mathrm{SCFAs}} / \mathrm{L}$ for the $S / I=1$ (results for non-inoculated sludge were not provided). Regardless of the S/I ratio selected, acetic acid was the dominant product, followed by propionic, butyric, and n-valeric acids. Nevertheless, the butyric acid concentration increased with the S/I ratio; meanwhile, the proportion of acetic acid decreased. The authors proposed that higher S/I ratios involved higher organic loads, higher accumulation of SCFAs and, subsequently, a decrease of $\mathrm{pH}$, favoring the long-chain fatty acids production.

\subsubsection{Biological Hydrolysis with Additives Effect of Cation Exchange Resins}

The use of cation exchange resins (CER) is an interesting approach to promote the sludge solubilization due to the recoverability and reusability of these. In this sense, Pang et al. [20] fermented a secondary sludge at $35^{\circ} \mathrm{C}$ for 12 days and in the presence of different CER dosages (from 0 to $3.5 \mathrm{~g} / \mathrm{g}$ SS). This CER was able to exchange its $\mathrm{Na}^{+}$cations with the multivalent ones present in the flocs, thus disrupting their structure and improving the cell breakage. As expected, higher dosages of resin led to higher solubilization. As an example, the $\mathrm{SCOD} / \mathrm{SCOD}_{\mathrm{o}}$ ratio at the end of the fermentation without CER was 8 , but it was raised up to 25.6 if $1.75 \mathrm{~g}$ CER/g SS were added. Nevertheless, as authors stated, increasing the CER dosage beyond $1.75 \mathrm{~g} / \mathrm{g}$ SS did not involve a significant improvement in terms of sludge solubilization. The same trend was also found during the SCFAs production, where maximum SCFAs concentrations were 1279, 4415, or $4727 \mathrm{mg}$ COD/L after 4-day fermentation in the absence or presence of 1.75 or $3.5 \mathrm{~g} \mathrm{CER/g} \mathrm{SS}$, respectively, with the SCFAs/SCOD ratio remaining almost constant in a value of around 0.67.

Putting the light on the SCFAs compositions, CER dosages higher than $1.75 \mathrm{~g}$ CER/g SS had a negligible effect in SCFAs profiles, with the following mean proportions: $40 \%$ 
acetic acid, 18.5\% propionic acid, 15\% n-butyric acid, 15\% iso-valeric acid, $8 \%$ iso-butyric acid, and finally, 5\% n-valeric acid. However, this SCFAs profile strongly differed to that found in presence of lower CER dosage, which favored the propionic acid production in comparison to other acids.

These authors complemented this approach in a subsequent article [67], where a central composite design (CCD) evaluated by response surface methodology (RSM) was carried out to find optimal conditions of CER dosage (0.25-3.25 g/g SS), fermentation time (1-8 days), and stirring strength (50-400 rpm) in terms of disintegration degree and of SCFAs production. Results showed that the optimal inputs were $1.78 \mathrm{~g}$ CER/g SS, 6.46 days, and $261.2 \mathrm{rpm}$, which led to a disintegration degree of $42.8 \%$ and a SCFAs concentration of $4570.5 \mathrm{mg} \mathrm{COD} / \mathrm{L}$. As can be checked, these results are not far away from the best conditions obtained in the previous study [20]. The authors stated that when the input factors were lower than the corresponding optimal parameters, the removal efficiency of multivalent cations was increased as the increase of CER dosage, while the increased stirring strength was beneficial for the cation transfer via thorough sludge-CER mixing. However, the further increase in input factors did not improve sludge solubilization and SCFAs production because either CER dosage, stirring strength, or treatment time were high enough to not involve a significant effect on sludge solubilization.

\section{Effect of Sand}

The use of inert additives as promoters for sludge acidogenic digestion was explored by Jiang et al. [68]. These authors studied the fermentation of waste activated sludge in batch $\left(37^{\circ} \mathrm{C}, 14\right.$ days, initial $\left.\mathrm{pH} 10\right)$ employing different superfine sand dosages (VSS/TSS ratios from $63 \%$, for control without sand, to $45 \%$ ). Sand acted as fermentation enhancer, which promoted the sludge hydrolysis by creating shear forces on the cells during the stirring. The effect of superfine sand on the solubilization stage was also characterized by measuring soluble protein and carbohydrate contents.

As expected, because of the presence of superfine sand, more shear force was generated, which accelerated the destruction of extracellular polymers, thus increasing the solubilization at high sand dosages. However, results also revealed that superfine sand had no effect on the subsequent hydrolysis rate of soluble organic materials in sludge, from proteins and carbohydrates to amino acids and monosaccharides. The authors reported that SCFAs production during WAS anaerobic fermentation was positively affected by superfine sand, as indicated by an increase of 1.2 times after 4 days, from $2513 \mathrm{mg}$ COD/L without superfine sand to $3002 \mathrm{mg}$ COD/L with superfine sand (VSS/TSS $=50 \%$ ). Nevertheless, higher sand dosages worsened SCFAs production, which was probably due to excessive shear forces that can also affect SCFA-producing microorganisms. Regarding the final distribution of SCFAs, acetic, propionic and valeric acid played dominant roles, although butyric acid was also present in significant proportions. When superfine sand was present in the WAS, the production of acetic and valeric acids was boosted.

\section{Effect of Oxidants}

Another way to enhance the classical biological process is the incorporation of different chemicals to the fermentation medium, which act as oxidants and solubilize the sludge. This facilitates the hydrolysis step, which is considered the limiting one in the biological digestions, as previously explained.

This was the strategy followed by Luo et al. [69], who carried out classical acidogenic fermentations in the presence of $\mathrm{Fe}(0)(1.25 \mathrm{mM} / \mathrm{g}$ TSS), persulfate (PS) $(1.0 \mathrm{mM} / \mathrm{g}$ TSS), and the combination of both (Fe(0)/PS) $(1.25 / 1.0 \mathrm{mM}) / \mathrm{g}$ TSS). All the fermentations were conducted with sedimented secondary sludge in stirred batch reactors at a temperature of $35{ }^{\circ} \mathrm{C}$ and without $\mathrm{pH}$ control. The authors reported that the solubilization and hydrolysis efficiencies were mildly improved with the sole Fe treatment, whereas the contributing effect was further enhanced remarkably with the involvement of PS. As a strong oxidant, PS was able to chemically disrupt the EPS structure and result in the release of substrates. 
The disruptive effects of PS were aggravated due to the generation of strong oxidizing sulfate radicals with the activation of Fe. Surprisingly, the maximal concentration of soluble substrates was observed in PS reactor and not in the PS/Fe one. The authors attributed this fact to the higher reactivity of sulfate radicals, compared with PS, thus causing a more severe inhibition on the hydrolases activity.

Moving on to the SCFAs profiles, acetic acid predominated when PS was present, individually or together with Fe (76.9\% and $66.5 \%$ for Fe + PS and PS alone, respectively). In the absence of PS, these percentages decreased drastically $(37.1 \%$ and $21.9 \%$, for Fe alone and control, respectively). It should be noticed that although propionic acid was the main SCFAs at the end of sludge fermentations either without additives or with sole Fe $72.8 \%$ and $53 \%$, respectively), the presence of PS in the medium highly inhibited its formation ( $9.7 \%$ and $4.9 \%$ for Fe + PS and PS alone, respectively). Moreover, PS favored the presence of valeric acid ( $8.1 \%$ and $11.2 \%$ for Fe + PS and PS alone, respectively). Butyric acid was present in all cases, although its proportion did not follow a clear pattern.

Due to the promising results obtained, Luo et al. [70] also evaluated the roles of peroxydisulfates (PDS), and different iron forms as enhancers for acidogenic fermentations. To this purpose, they carried out batch fermentations at $35^{\circ} \mathrm{C}$ for 14 days, adding three different iron forms $\left(\mathrm{Fe}^{2+}, \mathrm{ZVI}\right.$ (zero-valent iron), and NZVI (nano zero-valent iron)) to a settled secondary sludge already containing PDS.

Experiments revealed that the most efficient activation of PDS was achieved by $\mathrm{Fe}^{2+}$, as well as promoting a best sludge dewatering and the highest VSS reduction. Thus, maximum SCFAs accumulation with PDS $+\mathrm{Fe}^{2+}$ was $5537 \mathrm{mg}$ COD/L after 10 days, this being clearly higher than those achieved with other iron forms (3036 mg COD/L for PDS + ZVI, $3533 \mathrm{mg}$ COD/L for PDS + NZVI—in this case after 8 days-and $702 \mathrm{mg}$ COD/L for control). In any case, the SCFAs production was clearly diminished with no chemical addition (PS or activator), with the highest accumulation for the control reactor of only $702 \mathrm{mg}$ COD/L after 10 days. Again, the synergistic effects of PDS and activators in contributing to SCFAs promotion were clearly demonstrated.

Regarding the effects of these activators on the SCFAs final composition, the addition of PDS and any iron form sharply increased the production of acetic acid, from $13.8 \%$ for the control to $59.6 \%$ with PDS + $\mathrm{Fe}^{2+}, 66 \%$ with PDS + NZVI or $72.2 \%$ with PDS + ZVI. On the contrary, these compounds also lowered propionic acid formation from $61.1 \%$ for the control to $7.6 \%$ with PDS + $\mathrm{Fe}^{2+}, 20 \%$ with PDS + NZVI and $9.8 \%$ with PDS + ZVI. The changes in other SCFAs (for instance, $\mathrm{n}$ and iso-butyric and $\mathrm{n}$ and iso-valeric acids) due to the presence of the different iron forms and PDS were less marked. As an example, n-butyric presence was not detected for control and PDS + NZVI fermentations but represented a $1.3 \%$ and an $11.4 \%$ of the total SCFAs for the PDS + ZVI and PDS+ $\mathrm{Fe}^{2+}$ fermentation.

\subsection{Separated Hydrolysis and Fermentation}

2.3.1. Chemical Hydrolysis

Effect of $\mathrm{CaO}$

The SCFAs production by acidogenic fermentation of sludge previously subjected to a chemical solubilization by adding calcium oxide $(\mathrm{CaO})$ was assayed by $\mathrm{Xin}$ et al. [71]. Focusing firstly on the chemical solubilization, a waste-activated sludge was subjected to a 15-h treatment under different $\mathrm{CaO}$ dosages, from 0 to $0.07 \mathrm{~g} \mathrm{CaO} / \mathrm{g}$ TS. As expected, the higher the $\mathrm{CaO}$ dosage, the greater the sludge solubilization, with the SCOD/SCOD $\mathrm{O}$ at the end of the pretreatment ranging from no variation, in the absence of $\mathrm{CaO}$, to 15.14 with a dosage of $0.07 \mathrm{~g} \mathrm{CaO} / \mathrm{g}$ TS. During the sludge solubilization, $\mathrm{CaO}$ generated hydroxy radicals, which promoted the dissolution of flocs, and at the same time, $\mathrm{Ca}^{2+}$ affected the sludge floc structure via bonding with functional groups, thus also improving the solubilization.

After the $\mathrm{CaO}$ pretreament, $\mathrm{Xin}$ et al., [71] compared the acidogenic fermentations of the non-pretreated sludge (OLR $\left.=0.005 \mathrm{~g} \mathrm{COD} \mathrm{L}^{-1} \mathrm{~d}^{-1}\right)$ and the hydrolysate obtained by 
treating the sludge with $0.07 \mathrm{~g} \mathrm{CaO} / \mathrm{g} \mathrm{TS}\left(\mathrm{OLR}=0.073 \mathrm{~g} \mathrm{COD} \mathrm{L}^{-1} \mathrm{~d}^{-1}\right)$. The conditions of fermentation involved perfect mixing, an HRT of 16.7 days, and a temperature of $35^{\circ} \mathrm{C}$. However, even though authors indicated that $\mathrm{pH}$ was measured, these data did not appear reported throughout the text. Maximum SCFAs concentration was achieved with the $\mathrm{CaO}$ pretreated hydrolysate tests after 6 days, being 1.5-fold higher than for the control test at the same time (2611 $\mathrm{mg}$ COD/L and $1800 \mathrm{mg}$ COD/L, respectively).

Additionally, the microbial diversity was shifted in CaO-pretreated sludge fermentation. However, SCFAs profiles at this point were quite similar, regardless of the previous addition of $\mathrm{CaO}$ to sludge. Thus, the main acid was n-butyric (34\% for control and 32\% with pretreamtent), followed by acetic acid (25\% and $28 \%)$, iso-valeric acid (12\% and 15\%), propionic ( $8 \%$ and $10 \%)$, iso-butyric (13\% and $9 \%$ ), and $n$-valeric acids $(7 \%$ and $5 \%$ for pretreated sludge). As can be observed, there is a relatively high abundance of SCFAs with "long" chains (butyric and valeric acids), which is a phenomenon that the authors linked to a high content of proteins in the hydrolysates, although this was not experimentally checked.

\section{Effect of Surfactants}

Wan et al. [72] tested the effect of sodium dodecylbenzene sulfonate (SDBS) addition as a pretreatment method on the SCFAs production. To this end, $0.01 \mathrm{~g}$ SDBS/ $\mathrm{g}$ TS were added to a secondary settled sludge, which after $1 \mathrm{~h}$ at room temperature was fermented, comparing the results with the fermentation of the same sludge in the absence of SDBS. After a week of fermentation at $35^{\circ} \mathrm{C}$, it was checked that SDBS significantly improved the production of SCFA from $60 \mathrm{mg}$ COD $\mathrm{g}$ VS-1 to $170 \mathrm{mg}$ COD $\mathrm{g}$ VS-1. In addition, the presence of SDBS also had an impact on the SCFAs distribution, favoring the production of acetic and n-butyric acids in comparison to propionic acid. In fact, propionic acid was the main acid in the control fermentation (38\%) but not in the presence of SDBS, where acetic acid turned out to be the predominant one (37\%), being lowered the content in propionic acid to $18.6 \%$. The percentages for all the other acids did not change when adding SDBS: iso-valeric acid (21\%), iso-butyric acid (11\%), n-butyric acid (6\%), and n-valeric acid (3\%).

\subsubsection{Thermal Hydrolysis}

This section involves all the recent studies dealing with thermal hydrolysis as sludge pretreatment for the subsequent acidogenic fermentation of the hydrolysate obtained.

\section{Effect of Inoculum Size}

Iglesias-Iglesias et al. [66] evaluated the combined effects of using a thermal pretreatment and inoculum size $\left(120^{\circ} \mathrm{C}\right.$ and $2 \mathrm{bar}$ for $\left.15 \mathrm{~min}\right)$ on the SCFAs production. By means of the application of the thermal pretreatment, the SCOD increased $16 \%$, as well as the concentrations of $\mathrm{N}-\mathrm{NH}_{4}{ }^{+}$and $\mathrm{P}-\mathrm{PO}_{4}{ }^{-3}$ (5\% and 19\%, respectively). Another effect of the thermal treatment was a $4 \%$ reduction in total COD (TCOD) due to the loss of volatile soluble compounds. Then, the hydrolysate obtained was inoculated with the microbiota of an anaerobic digestor at different S/I ratios, ranging from 1 to $6 \mathrm{~g}$ VS substrate/g VS inoculum, and fermented at $30^{\circ} \mathrm{C}$ for 30 days without $\mathrm{pH}$ control.

Researchers found a higher SCFAs production with compared to without thermal pretreatment, although this difference was less marked at high S/I, at which the maximum acidogenic potential was found (9500 $\mathrm{mg} \mathrm{CODSCFAs}^{-1}$ after 10 days). As in the case of the raw sludge fermentation (see Effect of Inoculum Size paragraph in Section 2.2.1), the higher the S/I ratio, the higher the SCFAs accumulation after the fermentation of the thermally hydrolyzed sludge. However, when authors calculated the degree of acidification, (the amount of acids generated per unit of initial TCOD), this was found to be higher when larger inocula were used for fermenting the thermally hydrolyzed sludge, ranging from $45 \%$ for $\mathrm{S} / \mathrm{I}=1$ to $37 \%$ for $\mathrm{S} / \mathrm{I}=6$. Therefore, low inoculum sizes produced more concentrated but less pure streams of SCFAs at the end of the fermentation. In any case, higher degrees of acidification were observed when the sludge was thermally pretreated, especially at low 
S/I ratios. Finally, in comparison to the non-pretreated sludge, the thermal pretreatment also modified the final SCFAs profile, enhancing the proportions of propionic, iso-butyric, $\mathrm{n}$-butyric, iso-valeric, and n-valeric acids at all the $\mathrm{S} / \mathrm{I}$ ratios tested.

\section{Effect of Surfactants}

The combination of pretreatments is also feasible. This is the case of Wan et al. [72], who tested the efficiency of combining SDBS and low-thermal pretreatment to improve the production of SCFAs from a secondary settled sludge. To this end, sewage sludge was firstly subjected to a thermal treatment $\left(1 \mathrm{~h}, 70^{\circ} \mathrm{C}\right)$ in the presence of different SDBS dosages (from 0 to $0.02 \mathrm{~g} / \mathrm{g}$ TS) and then fermented in batch reactors at $35^{\circ} \mathrm{C}$ for a week without employing an inoculum.

From the characteristics of hydrolysates obtained after the different pretreatments, it clearly emerged that the combination of SDBS and thermal treatment was the most effective option to solubilize the sludge. Thus, the SDBS addition $(0.01 \mathrm{~g} / \mathrm{g}$ TS $)$ during the thermal pretreatment increased around 20\% the SCOD in the hydrolysate in comparison to the sole low thermal treatment. Meanwhile, the combination of temperature and SDBS also made it possible to enhance by $768 \%$ the final SCOD with respect to the sole SDBS pretreatment. Comparatively, sole thermal pretreatment was clearly more effective than sole SDBS dosage solubilizing the sludge.

The combined SDBS and thermal pretreament was also the most effective in terms of acidogenic potential of the hydrolysate obtained. The maximum SCFAs concentration was obtained after 4 days of fermentation of the sludge previously hydrolyzed by a combination of thermal treatment and $0.01 \mathrm{~g}$ SDBS/g TS, with a value of $320 \mathrm{mg}$ COD/g VS. This value was 1.8, 1.7, and 4.0 times higher than those from sole low-thermal, sole SDBS, and the control test, respectively. It can be stressed that the dosage of more than $0.01 \mathrm{~g}$ SDBS $/ \mathrm{g}$ TS resulted in a toxic effect during the acidogenic fermentation, which not only led to a reduction in the maximum SCFAs concentration but also to a delay in the time at which it was reached.

Focusing on the SCFAs profiles, these differed depending on the pretreatment chosen. First of all, the SCFAs profile for the control test was $21 \%$ of acetic acid, $38 \%$ of propionic acid, $12 \%$ of iso-butyric acid, $5 \%$ of n-butyric acid, $2 \%$ of n-valeric acid, and $22 \%$ of isovaleric acid. The employment of a low thermal treatment involved a clear increase in acetic acid (up to $62.6 \%$ ) and an impoverishment in propionic, iso-butyric, and iso-valeric acid percentages (down to $15.4 \%, 3 \%$, and $14 \%$, respectively). The presence of SDBS $(0.01 \mathrm{~g} / \mathrm{g}$ TS) during the thermal pretreatment caused slight decreases in the acetic (from $62.6 \%$ to $56.4 \%$ ) and iso-valeric acids percentages and, therefore, slight increases in the propionic, butyric, and n-valeric acids.

\section{Polyhydroxyalkanoates}

\subsection{General Considerations}

Although the methods described in the previous section generate added value products from sewage sludge, there are more alternatives comprising both sludge management and circular economy to be explored. In this regard, taking into account that society is currently more aware than ever of the problems generated by petrol-based plastics, the demand of new green materials that could replace them is opening up new opportunities for the sludge valorization. Among these green materials, ones with high potential are PHAs, which are biopolymers mainly composed by polyhydroxybutyrate (PHB) monomers, although polyhydroxyvalerate (PHV) is often found in their composition as well [73].

Chemically, PHAs are polyesters that microorganisms use as energy storage $[74,75]$. PHAs composition is similar to polypropylene; therefore, they can substitute petrol-based plastics. In fact, their use has been explored in the packaging of cosmetics or feminine hygiene products, food coatings, formulation of wood composites, and 3D printing inks, among others. Due to their biocompatibility, PHAs have also been employed in several fields of medicine, such as tissue engineering, repairing blood vessels, nerves conduits, 
artificial heart valves or implants, or as drug carrier material. Other applications for PHAs included their use as encapsulation material for enzymes, fertilizers or insecticides, or as materials to cover and protect the growing plants, the synthesis of chiral compounds or, even, their depolymerization to obtain platform molecules for further uses [75-79]. The economic aspects of PHAs production can be found elsewhere in the literature [80,81].

Although several types of species can synthesize PHAs, the ones here meaningful are bacteria, owing to its predominant proportion in sewage sludge and their faster growth abilities. The biochemical mechanism of PHAs accumulation by bacteria during WWTPs operation is well studied, so it is not required to be detailed here [82]. Suffice it to say that PHAs production naturally occurs in WWTPs simultaneously with phosphorus removal, since this biopolymer is naturally accumulated by bacteria under situations of anaerobiosis (and in absence of either nitrites and nitrates) by means of the uptake of low-complex carbon molecules, such as SCFAs, which can be easily obtained from sludge [82]. It is interesting to note that several studies have showed that some microorganisms were able to accumulate even more PHAs in aerobic conditions [82-84].

Given that SCFAs are the main substrate for PHA-producing microorganisms and their presence in raw sludge is low, a previous sludge acidogenic fermentation is required, although other non-biological pretreatments are also possible for this purpose, as will be explained ahead. In any case, the PHA-producing reactor feeding should have a significant content of SCFAs in its composition, since it is proved that the presence in a proportion higher than $30 \%$ of other carbon molecules, such as proteins or carbohydrates, largely hinders the PHAs accumulation $[85,86]$. Consequently, all those methods employed to enhance SCFAs production from sludge (see previous section) also represent an excellent pretreatment to improve the subsequent PHAs accumulation.

PHAs production not only depends on the total concentration of SCFAs but also on the profile of these. Thus, the presence of a high proportion of acids with an even number of carbon atoms, such as acetic or butyric acids, is a determining factor during the PHAs accumulation by microorganisms, although this phenomenon will be checked and discussed after the description of the studies [87]. Soluble nitrogen concentration plays another important role in the final PHAs production, since nitrogen is needed for cellular metabolism. Particularly, the higher the $\mathrm{C} / \mathrm{N}$ ratio, the higher the PHAs accumulation, at least in ranges of $\mathrm{C} / \mathrm{N}$ (in mass basis) lower or equal to 144 [88].

In the following paragraphs, the most recent studies dealing with PHAs production from hydrolyzed sludge obtained by different pretreatments will be discussed. It must be pointed out that only works where the feeding of the PHA-producing step is clearly detailed were included. A summary of these studies can be found in Table 2. 
Table 2. Summary of the main parameters found in the studies dealing with PHAs production.

\begin{tabular}{|c|c|c|c|c|c|c|c|}
\hline \multirow{2}{*}{ Sludge } & \multicolumn{2}{|c|}{ Thermal Treatment } & \multicolumn{2}{|c|}{ Acidogenic Fermentation } & \multicolumn{2}{|c|}{ PHA Fermentation } & \multirow{2}{*}{ References } \\
\hline & Conditions & Results & Conditions & Results & Conditions & Results & \\
\hline Settled activated sludge & & & $\begin{array}{c}\text { Spontaneous } \\
\text { fermentation at } 36^{\circ} \mathrm{C}, \\
100 \text { rpm for } 1 \text { day } \\
\text { Different pHs: } 10.0,9.0, \\
8.0,7.0,6.0,5.0 \text {, and } 4.0\end{array}$ & $\begin{array}{c}\text { Better SCFAs/SCOD } \\
\text { results at pH } 10.0,9.0 \\
\text { and } 4.0: 61.8 \%, 57.0 \%, \\
\text { and } 58.0 \% \text { respectively } \\
\text { Mainly acetic acid, } \\
\text { propionic acid, and low } \\
\text { valeric acid quantities }\end{array}$ & $\begin{array}{c}\text { Seed sludge acclimated in } \\
\text { ADF }(10 \% \text { of inoculum }) \text { at } \\
25^{\circ} \mathrm{C} \text { in SBR for at least } 3 \\
\text { cycles of } 12 \mathrm{~h} \\
\text { Feeding of SCFAs liquid, } \\
\text { nutrient solution of } \mathrm{N} \text { and } \mathrm{P}, \\
\text { trace elements and seed } \\
\text { sludge } \\
\text { Five stages per cycle in a } \\
\text { SBR at } 25^{\circ} \mathrm{C} \text { : influent }\left(5^{\prime}\right), \\
\text { anaerobic with mixing }\left(25^{\prime}\right), \\
\text { aerobic }\left(660^{\prime}\right) \text {, settling }\left(25^{\prime}\right), \\
\text { and effluent }\left(5^{\prime}\right)\end{array}$ & $\begin{array}{l}\text { 0.6 g PHA/g VSS using } \\
\text { pH 10 SCFAs liquid } \\
\text { after } 0.5 \mathrm{~h} \\
\text { Mainly composed of } \\
\text { PHB }(>90 \%)\end{array}$ & (Liu et al., 2020) \\
\hline $\begin{array}{l}\text { Sludge from thickening } \\
\text { tank (lab-scale } \\
\text { experiments) } \\
\text { Diluted dewatered } \\
\text { sludge (pilot-scale } \\
\text { experiments) }\end{array}$ & & & $\begin{array}{c}\text { Lab-scale: spontaneous } \\
\text { fermentation at } 40^{\circ} \mathrm{C} \text {, } \\
1200 \text { rpm without } \mathrm{pH} \\
\text { control } \\
\text { Pilot scale: } 50^{\circ} \mathrm{C}\end{array}$ & $\begin{array}{l}55.83 \% \text { and } 65.17 \% \text { of } \\
\text { SCFA/COD for } \\
\text { lab-scale and pilot scale } \\
\text { respectively. } \\
\text { Mainly acetic acid, } \\
\text { similar concentrations } \\
\text { of propionic acid, } \\
\text { butyric acid, and } \\
\text { iso-valeric acid }\end{array}$ & $\begin{array}{l}\text { Seed sludge from secondary } \\
\text { sedimentation tank } \\
\text { acclimated in synthetic } \\
\text { media at } 30^{\circ} \mathrm{C} \text { and } \mathrm{pH} 7 \mathrm{in} \\
\text { at least } 3 \text { cycles in } \\
\text { feast-famine strategy } \\
\text { Lab scale: } 30^{\circ} \mathrm{C}, 150 \mathrm{rpm} \\
\text { and } \mathrm{pH} 7 \text { for } 60 \mathrm{~h} \\
\text { Pilot scale: feast-famine } \\
\text { cycles }\left(120 \mathrm{~h} \text { ) at } 30^{\circ} \mathrm{C}, 150\right. \\
\text { rpm without } \mathrm{pH} \text { control }\end{array}$ & $\begin{array}{c}0.23 \mathrm{~g} \text { PHA/g dry cell } \\
\text { after } 36 \mathrm{~h} \\
0.59 \mathrm{~g} \text { PHA /g dry cell } \\
\text { after } 72 \mathrm{~h} \text { and } 4 \text { batch at } \\
\text { pilot scale }\end{array}$ & (Jia et al., 2014) \\
\hline $\begin{array}{l}\text { Thickened } \\
\text { waste-activated sludge }\end{array}$ & & & $\begin{array}{c}\text { Spontaneous } \\
\text { fermentation at } 35^{\circ} \mathrm{C}, \\
42^{\circ} \mathrm{C} \text { and } 55^{\circ} \mathrm{C} \text { in } 10 \\
\text { days batches. No pH } \\
\text { control }\end{array}$ & $\begin{array}{l}90 \% \text { of SCFA/SCOD at } \\
42^{\circ} \mathrm{C} \text { and } 4-5 \text { days (the } \\
\text { best condition) } \\
\text { Mainly acetic acid }(38 \%) \\
\text { followed by butyric } \\
\text { acid ( } 20 \% \text { ) and similar } \\
\text { percentages of } \\
\text { propionic, valeric and } \\
\text { iso-valeric acids }(\approx 10 \%)\end{array}$ & $\begin{array}{c}\text { Seed sludge from a SBR } \\
\text { treating real wastewater in } \\
\text { feast-famine }(12 \text { cycles a } \\
\text { day) } \\
\text { Production by } \\
\text { feed-on-demand. } \\
\text { Temperature and pH not } \\
\text { controlled. Different } \\
\text { accumulation times }\end{array}$ & $\begin{array}{c}\text { Maximum of } 0.38 \mathrm{~g} \\
\mathrm{PHA} / \mathrm{g} \text { VSS }\left(22-25{ }^{\circ} \mathrm{C},\right. \\
\mathrm{pH} \text { ranging from } 7.5 \text { to } \\
8.1) \text { after } 15 \mathrm{~h} \\
70 \% \text { of PHB, } 30 \% \text { of } \\
\mathrm{PHV} \text { (mean values) }\end{array}$ & $\begin{array}{l}\text { (Morgan- } \\
\text { Sagastume et al., } \\
\text { 2015) }\end{array}$ \\
\hline $\begin{array}{l}\text { Secondary from } \\
\text { sedimentation tank }\end{array}$ & & & $\begin{array}{c}\text { Spontaneous } \\
\text { fermentation in } \\
\text { anaerobiosis } \\
\text { Different temperatures } \\
\text { and pHs: } 21,35,60^{\circ} \mathrm{C} \text {; } \\
\text { pH } 8,9,10, \text { and } 11 \\
\text { Addition of } 0.02 \mathrm{~g} / \mathrm{g} \\
\text { VSS of SDBS }\end{array}$ & $\begin{array}{l}\text { Optimal conditions: } \\
60^{\circ} \mathrm{C} \text { and pH } 11.0 \\
2.56 \mathrm{~g} \text { SCFA } / \mathrm{L} \text { as TOC } \\
\text { Mainly acetic acid } \\
(80.5 \%) \text { and propionic } \\
\text { acid }(11.4 \% \text {. Lower } \\
\text { concentrations of } \\
\text { butyric and valeric } \\
\text { acids and their isomers }\end{array}$ & $\begin{array}{c}\text { Sludge from aeration tank } \\
\text { without acclimationFeeding } \\
\text { in three pulses, when } \\
\text { substrate exhausted } \\
21{ }^{\circ} \mathrm{C} \text {, no pH control, } 250 \\
\text { rpm }\end{array}$ & $\begin{array}{c}0.565 \mathrm{~g} \text { PHA } / \mathrm{g} \text { dry cell } \\
\text { after } 3 \mathrm{~h} 40^{\prime} \\
88.1 \% \text { of PHB, } 11.9 \% \text { of } \\
\text { PHV }\end{array}$ & $\begin{array}{l}\text { (Mengmeng et al., } \\
\text { 2009) }\end{array}$ \\
\hline
\end{tabular}


Table 2. Cont

\begin{tabular}{|c|c|c|c|c|c|c|c|}
\hline \multirow{2}{*}{ Sludge } & \multicolumn{2}{|c|}{ Thermal Treatment } & \multicolumn{2}{|c|}{ Acidogenic Fermentation } & \multicolumn{2}{|c|}{ PHA Fermentation } & \multirow{2}{*}{ References } \\
\hline & Conditions & Results & Conditions & Results & Conditions & Results & \\
\hline $\begin{array}{l}\text { Chemically enhanced } \\
\left(\mathrm{FeCl}_{3}\right) \text { sedimentation } \\
\text { primary sludge }\end{array}$ & & & $\begin{array}{c}\text { Spontaneous } \\
\text { fermentation at } 37^{\circ} \mathrm{C} \text {. } \\
\text { No pH control } \\
\text { Addition of different } \\
\mathrm{CaO}_{2} \text { concentrations to } \\
\text { enhance hydrolysis }\end{array}$ & $\begin{array}{c}\text { Better results with } 0.1 \mathrm{~g} \\
\mathrm{CaO}_{2} / \mathrm{g} \text { VSS: } 93.5 \% \\
\text { SCFAs/SCOD after } 16 \\
\text { days } \\
\text { Mainly propionic and } \\
\text { acetic acids ( } 50 \% \text { and } \\
35 \% \text { respectively) } \\
\text { followed by a } 10 \% \text { of } \\
\text { iso-valeric acid }\end{array}$ & $\begin{array}{c}\text { SBR (feast-famine) with } \\
\text { activated sludge as } \\
\text { inoculum. } 21^{\circ} \mathrm{C} \text { with SRT of } \\
10 \text { days }\end{array}$ & $\begin{array}{l}\text { Maximum of } 0.223 \mathrm{~g} \\
\text { PHA/g VSS at day } 35 \\
\text { Polymer made of equal } \\
\text { parts of PHB and PHV }\end{array}$ & (Xu et al., 2018) \\
\hline $\begin{array}{c}\text { Municipal and primary } \\
+ \text { municipal } \\
\text { waste-activated sludge } \\
\text { subjected to a } \\
\text { CAMBI }^{\mathrm{TM}} \text { process }\end{array}$ & & & $\begin{array}{c}\text { Semi-continuous } \\
\text { spontaneous } \\
\text { fermentation at } 42{ }^{\circ} \mathrm{C}, \\
20-30 \mathrm{~g} / \mathrm{L} \mathrm{d} \text { of organic } \\
\text { load rate }\end{array}$ & $\begin{array}{l}\text { In mix of sludges, } 50 \% \\
\text { SCFAs /SCOD with } \\
\text { predominance of acetic } \\
\text { acid }(\approx 27 \%) \text { and } \\
\text { butyric acid }(\approx 23 \%), \\
\text { similar proportions of } \\
\text { propionic and valeric } \\
\text { acids }(\approx 17 \%) \text { and lower } \\
\text { representation of } \\
\text { valeric, caproic and } \\
\text { isobutyric acids } \\
\text { In only municipal } \\
\text { sludge: } 58 \% \\
\text { SCFAs/SCOD, being } \\
\text { acetic acid the main one } \\
(\approx 32 \%) \text { followed by } \\
\text { butyric acid and } \\
\text { propionic acid }(\approx 18 \%), \\
\text { isovaleric acid }(\approx 14 \%) \\
\text { and isobutyric and } \\
\text { valeric acids }(\approx 8 \%)\end{array}$ & $\begin{array}{l}\text { SBR reactor in feast-famine } \\
\text { regime, with activated } \\
\text { sludge as inoculum, } \\
\text { controlled at } 35^{\circ} \mathrm{C} \text { and } 400 \\
\text { rpm. No pH control. Cycles } \\
\text { of } 4 \mathrm{~h}\end{array}$ & $\begin{array}{c}0.2 \mathrm{~g} \text { PHA } / \mathrm{g} \text { TSS } \\
\text { Polymer made of a } 74 \% \\
\text { of PHB and a } 26 \% \text { of } \\
\text { PHV }\end{array}$ & $\begin{array}{l}\text { (Morgan- } \\
\text { Sagastume et al., } \\
\text { 2010) }\end{array}$ \\
\hline $\begin{array}{l}\text { Primary + secondary } \\
\text { sludge }\end{array}$ & $\begin{array}{c}155-175^{\circ} \mathrm{C}, 6 \text { bar for } 30 \\
\min (\text { (CAMBI) }\end{array}$ & $\begin{array}{c}\text { Increase of SCOD (from } \\
2 \% \text { to } 27 \% \text { ), proteins } \\
\text { (from } 1 \% \text { to } 50 \% \text { ) and } \\
\text { carbohydrates (from } 1 \% \\
\text { to } 69 \% \text { ) } \\
\text { Little effect on SCFAs: } \\
\text { only } 0.3 \% \text { more in TH } \\
\text { sludge }(1.1 \mathrm{~g} \text { SCOD } / \mathrm{L} \\
\text { and } 1.3 \text { gSCOD/L in } \\
\text { raw and TH sludge } \\
\text { respectively) }\end{array}$ & $\begin{array}{l}\text { Fermentation using } \\
\text { anaerobic digested } \\
\text { sludge as inoculum } \\
\text { Fermentations at } 35^{\circ} \mathrm{C} \\
\text { with TH sludge and } \\
\text { raw sludge; } 55^{\circ} \mathrm{C} \text { with } \\
\text { TH sludge and raw } \\
\text { sludge. No pH control } \\
\text { (ranging from } 6.0 \text { to } \\
\text { 6.6). First at batch mode } \\
\text { (10 days), then } \\
\text { semi-continuous with } \\
\text { SRT of } 4 \text { days. }\end{array}$ & $\begin{array}{c}71 \% \text { and } 62 \% \\
\text { SCFAs } / \mathrm{SCOD} \text { for raw } \\
\text { sludge at } 35^{\circ} \mathrm{C} \text { and } \\
55^{\circ} \mathrm{C} \text {, respectively } \\
50 \% \text { and } 45 \% \\
\text { SCFAs } / \mathrm{SCOD} \text { for raw } \\
\text { sludge at } 35^{\circ} \mathrm{C} \text { and } \\
55^{\circ} \mathrm{C} \text {, respectively } \\
\text { Mainly acetic acid } \\
(\approx 30 \%) \text {, followed by } \\
\text { butyric }(\approx 27 \%) \text {, valeric } \\
(\approx 24 \%) \text { and propionic } \\
\text { acids }(\approx 17 \%)\end{array}$ & $\begin{array}{l}\text { Inoculum from aeration tank } \\
\text { Feast-famine regime at } \\
35^{\circ} \mathrm{C} \text { and } 150 \mathrm{rpm} \\
\text { Organic load at } 5 \mathrm{~g} \mathrm{SCOD} / \mathrm{L}\end{array}$ & $\begin{array}{c}\text { Results from acidified } \\
\text { TH-sludge at } 35^{\circ} \mathrm{C} \\
\text { after } 15 \mathrm{~h} \text { in the eight } \\
\text { cycle: } 0.346 \mathrm{~g} \text { PHA } / \mathrm{g} \\
\text { dry cell } \\
70 \% \text { of PHB and } 30 \% \text { of } \\
\text { PHV }\end{array}$ & (Zhang et al., 2019) \\
\hline
\end{tabular}


Table 2. Cont

\begin{tabular}{|c|c|c|c|c|c|c|c|}
\hline \multirow{2}{*}{ Sludge } & \multicolumn{2}{|c|}{ Thermal Treatment } & \multicolumn{2}{|c|}{ Acidogenic Fermentation } & \multicolumn{2}{|c|}{ PHA Fermentation } & \multirow{2}{*}{ References } \\
\hline & Conditions & Results & Conditions & Results & Conditions & Results & \\
\hline $\begin{array}{l}\text { Waste sludge from } \\
\text { sedimentation tank }\end{array}$ & $\begin{array}{l}\text { Thermal treatment at } \\
60,80,100 \text {, and } 120^{\circ} \mathrm{C} \\
\text { for } 2 \mathrm{~h}\end{array}$ & $\begin{array}{l}55.4 \% \text { (the highest) } \\
\text { SCFAs/COD at } 60^{\circ} \mathrm{C} \\
\text { with higher proportion } \\
\text { of acetic acid than } \\
\text { propionic, butyric, or } \\
\text { valeric ones }\end{array}$ & & & $\begin{array}{c}\text { Seed sludge acclimated in } \\
\text { synthetic wastewater, SBR } \\
\text { with ADF at } 25^{\circ} \mathrm{C}, \mathrm{pH} 7.5 \text { in } \\
3 \text { cycles of } 12 \mathrm{~h} \\
\text { Feeding of thermally treated } \\
\text { liquid, nutrient solution of } \\
\mathrm{N} \text { and } \mathrm{P} \text {, trace elements, and } \\
\text { seed sludge } \\
\text { SBR with ADF at } 25^{\circ} \mathrm{C}, \mathrm{pH} \\
7.5 \text { in cycles of } 12 \mathrm{~h}\end{array}$ & $\begin{array}{c}0.241 \mathrm{~g} \mathrm{PHA} / \mathrm{g} \text { VSS } \\
\text { using } 60^{\circ} \mathrm{C} \text { liquid after } \\
1.5 \mathrm{~h} \\
\text { Mainly composed of } \\
\text { PHB }\end{array}$ & (Liao et al., 2018) \\
\hline $\begin{array}{l}\text { Mix of primary and } \\
\text { waste-activated sludge } \\
\text { with acidogenic } \\
\text { fermentation }\end{array}$ & $\begin{array}{c}240^{\circ} \mathrm{C} \text { and } 20 \text { bar with } \\
\mathrm{O}_{2} \text { (wet oxidation) }\end{array}$ & $\begin{array}{c}46 \% \text { SCFAs/TOC } \\
\text { Mainly acetic acid (74\%) } \\
\text { and lower proportions } \\
\text { of propionic acid (12\%) } \\
\text { and butyric acid }(8 \%)\end{array}$ & & & $\begin{array}{l}\text { Biomass conditioning in } \\
\text { SBR in } 12-\mathrm{h} \text { cycle of } \\
\text { feast-famine with effluent of } \\
\text { WO at } 800 \mathrm{mg} \mathrm{C} / \mathrm{L} \\
\text { Temperature and pH } \\
\text { controlled at } 30^{\circ} \mathrm{C} \text { and } \\
7.0-8.8 \text {, respectively }\end{array}$ & $\begin{array}{c}0.4 \mathrm{~g} \text { PHA } / \mathrm{g} \text { TSS } \\
\text { Polymer made of } 77 \% \\
\text { of PHB and } 23 \% \text { of } \\
\text { PHV }\end{array}$ & $\begin{array}{c}\text { (Wijeyekoon et al., } \\
\text { 2018) }\end{array}$ \\
\hline
\end{tabular}




\subsection{Biological Hydrolysates for PHAs Production}

\subsubsection{Non-Assisted Biological Procedures}

This section covers those studies dealing with the PHAs production from a sludge previously subjected to an acidogenic fermentation and without adding any reagent as the simplest approach to obtain these biopolymers.

\section{Effect of $\mathrm{pH}$}

In this light, Liu et al. [89] evaluated the effect of the initial $\mathrm{pH}$ on both SCFAs formation and subsequent PHAs production by fermentation, employing a settled activated sludge as feedstock. The initial $\mathrm{pH}$ values studied ranged from 4 to 10 , and the acidogenic fermentations were carried out at $36{ }^{\circ} \mathrm{C}$ for only 1 day.

As explained in previous sections, results confirmed that fermenting waste sludge under initially alkaline conditions was more beneficial to solubilize and release organic matters than under initial acidic or neutral conditions.

Initial $\mathrm{pH}$ also had impact on the release of nitrogen from sludge during the acidogenic fermentation, observing the highest $\mathrm{COD} / \mathrm{NH}_{4}{ }^{+}$ratios at alkaline conditions, with values of 19.5 and 15.96 for $\mathrm{pH} 9$ and $\mathrm{pH}$ 10, respectively. For lower initial $\mathrm{pH}$ values, this parameter ranged from $5.26(\mathrm{pH}=7)$ to $9.57(\mathrm{pH}=6)$. It was found that initial alkaline $\mathrm{pH}$ values enhanced the SCFAs production than acidic ones, obtaining hydrolysates with more than $50 \%$ of the soluble COD corresponding to SCFAs at initial pH values of $10(61.8 \%), 9$ (57\%) and, surprisingly, also at 4 (58\%). However, it should be notice that a lower soluble $\mathrm{COD}$ value was reported at $\mathrm{pH} 4$, with this being close to a half of that corresponding at initially alkaline $\mathrm{pH}$ values.

SCFAs profiles at the end of the acidogenic fermentations at different initial $\mathrm{pH}$ values were consistently dominated by acetic (45.0-74.2\%), propionic (8.8-47.0\%), butyric (3.9-20.0\%), and little of valeric (2.2-6.2\%) acid. It was observed that initial acidic $\mathrm{pH}$ during sludge fermentation favored the production of acetic acid, whereas alkaline conditions promoted the generation of butyric acid, and near neutral $\mathrm{pH}$ conditions sped up the formation of propionic acid and valeric acid.

Once acidogenic fermentation was completed, the different sludge hydrolysates obtained were fermented to produce PHAs. It was found that the maximal PHAs content accounted for $60.3 \%$ of the dry cell, and it was achieved employing the acidogenic liquid hydrolysate obtained from sludge at an initial $\mathrm{pH}$ of 10 . Under these conditions, the recovered polymer composition was $98.3 \%$ PHB and $1.7 \%$ PHV by mass. This PHAs accumulation was almost three times higher than the achieved using the hydrolysate from raw sludge at initial $\mathrm{pH} 7$ as substrate.

The effect of initial $\mathrm{pH}$ of the raw sludge on the final production and composition of PHAs was linked to the composition of the acidogenic liquid obtained. Exploring the preferential consumption of the organic acids, Liu et al. [89] found that PHA-storing microorganisms preferred SCFAs with an even number of carbon atoms as substrates. At the same time, the consumption of these even-number SCFAs also increased the proportion of PHB in the final polymer, whereas the bacterial uptake of odd-number SCFAs led to a higher production of PHV. Moreover, the authors also delved into the consumption of other non-SCFAs substrates available in the sludge hydrolysate after the acidogenic fermentation, such as proteins or fulvic and humic acids. They reported that protein concentration sharply decreased, with more than $70 \%$ of the solubilized protein consumed in less than an hour. On the contrary, humic-like substances were poorly metabolized during the PHA-producing fermentation. This is an interesting fact, since sludge hydrolysates usually present an important content of humic acids [31,43].

\section{Effect of Temperature}

Morgan-Sagastume et al. [90] subjected a thickened waste-activated sludge to a spontaneous acidogenic fermentation at temperatures ranging from 30 to $55^{\circ} \mathrm{C}$ at pilot scale 
for 10 days. The centrates obtained were subsequently used to accumulate PHAs, thus discussing the effect of temperature on either the production or composition of these.

These experiments revealed that the optimal temperature for SCFAs production was $42{ }^{\circ} \mathrm{C}$ - a temperature at which the SCFAs represented $90 \%$ of the soluble COD in the centrate after $4-5$ days of acidogenic fermentation. Nevertheless, WAS fermentation at 35 and $55{ }^{\circ} \mathrm{C}$ also produced SCFAs-rich centrates with lower but reasonably good SCFAs/SCOD ratios $(>70 \%)$, which are also amenable for use as substrate for PHAs production. It should be noticed that although higher temperatures solubilized more solids and increased the SCFAs specific production rates per loaded waste sludge, they also involved lower SCOD conversions into SCFAS. In fact, the maximum SCFAs volumetric concentrations achieved were not statistically significantly different among the three tested temperatures, with a mean value of around $8 \mathrm{~g} \mathrm{COD}_{\mathrm{SCFA}} / \mathrm{L}$. Differences in SCFAs profiles due to temperature were slight, with these being dominated by acetic $(28-38 \%$, COD basis), butyric (15-26\%), propionic (13-23\%), iso-valeric (12-18\%), and valeric (4-11\%) acids, with little of iso-butyric $(6-9 \%)$ and trace amounts of caproic $(<1 \%)$ acids.

Regrettably, Morgan-Sagastume et al. [90] only tested sludge hydrolysate obtained by acidogenic fermentation at $42{ }^{\circ} \mathrm{C}$ as substrate for the PHA-producing fermentation. The maximum PHAs accumulation reported was $0.39 \mathrm{~g}$ PHA/g VSS, which were constituted by a mixture of PHB (70\%) and PHV (30\%).

Mengmeng et al. [91] continued studying the effect of fermenting sludge at different temperatures (from 21 to $60^{\circ} \mathrm{C}$ ) on the PHA-producing potential of the acidic hydrolysates generated. Nevertheless, when comparing to Morgan-Sagastume et al. [90], two clear differences in the experimental procedures can be distinguished. Firstly, Mengmeng et al. [91] added sodium dodecylbenzene sulfonate (SDBS) at the dosage of $0.02 \mathrm{~g} / \mathrm{g}$ VSS in each batch experiment to improve sludge solubilization. Secondly, these authors also used $\mathrm{MgCl}_{2} \cdot 6 \mathrm{H}_{2} \mathrm{O}$ after the sludge fermentation to recover ammonium and phosphorus by struvite deposition, and to control the carbon to nitrogen ratio in the PHA-producing fermentation. As expected, during the fermentations, SCFAs concentration value increased gradually with the rise of temperature at each $\mathrm{pH}$ tested (from 8 to 11), which indicated that more soluble substrates were produced from particulate organics in excess sludge under the alkaline conditions. It was also found that $\mathrm{pH}$ lower than 9 favored the production of butyric and valeric acids. Under the best conditions ( $\mathrm{pH} 11,60^{\circ} \mathrm{C}$ and 6 days), the maximum yield of SCFAs was $258.65 \mathrm{mg}$ TOC/g VSS, with acetic and propionic acids being the main products. Specifically, after struvite recovery, sludge hydrolysate was mainly composed by acetic acid ( $80.5 \%$ - the highest found among all the revised studies), with $11.4 \%$ of propionic acid and a low presence of other SCFAs, such as iso-valeric $(2.2 \%)$, iso-butyric $(1.3 \%)$, n-butyric $(4.0 \%)$, and n-valeric acids $(0.6 \%)$. The reason for the high ratio of acetic acid to other SCFAs was attributed to the high protein and carbohydrate content $(55 \%)$ in the sludge of this study, which contributed to the generation of SCFAs with 2-5 carbon chains. Propionic, iso-butyric, $n$-butyric, iso-valeric, or $n$-valeric acids were easily biodegraded to form acetic acid and were not much accumulated in the anaerobic fermentation system.

As in the case of Morgan-Sagastume et al. [90], only the best centrate obtained ( $\mathrm{pH}$ 11, $60{ }^{\circ} \mathrm{C}$ ) was employed as substrate for the PHAs-producing fermentation by Mengmeng et al. [91]. It was reported a maximum accumulation of $56.5 \%$ of PHAs on a dry cell basis after $220 \mathrm{~min}$ of fermentation. As expected, acetic acid was again the most easily assimilable by PHA-producing microorganisms. Finally, due to the high percentage of acids with an even number of carbon atoms $(86 \%)$ in the hydrolysate, the PHA polymer was mainly composed by PHB (88.1\%).

\section{Effect of Scaling Up}

Jia et al. [85] studied the PHAs generation from excess sludge fermentation liquid at lab and pilot scale. For the former, PHAs-producing fermentations were carried out using either a hydrolysate obtained by acidogenic fermentation of thickened sludge at 
$40{ }^{\circ} \mathrm{C}$ in batch experiments or a simulated acidic centrate with a similar composition but prepared using commercial SCFAs, nitrogen, and phosphorus sources. On the other hand, a hydrolysate obtained by acidogenic digestion at $50{ }^{\circ} \mathrm{C}$ of a dewatered sludge in a real WWTP was employed for the pilot-scale fermentations.

Lab-scale PHAs fermentation in simulated sludge fermentation liquid produced a maximal PHAs content of $59.18 \%$ of the cell dry weight at $36 \mathrm{~h}$. The specific uptake rate of acetic acid was the highest, which was followed by butyric acid, and the last was propionic acid, which confirmed that PHA-producing consortium preferred to utilize even-number acids. On the other hand, employing a real centrate for lab tests, fermentation led to a significantly lower PHAs accumulation, with only around $25 \%$ of the dry cell weight after $36 \mathrm{~h}$. This lower value using the real centrate was attributed to a higher cell growth due to its lower SCFAs/SCOD ratio (56\%), in comparison to simulated fermentation liquid (96\%), which was almost completely composed of SCFAs. On the other hand, the highest PHAs production during the fermentation of the real acidogenic liquid at pilot scale was 59.47\% of the dry cell weight, once the consortium was completely adapted to the environment and obtained a high ability of PHAs synthesis in this pilot-scale reactor. This value was significantly greater than at lab scale. These authors proposed that the adverse impact of excess nitrogen and non-SCFAs fraction in the real centrate on PHAs accumulation might be eliminated by pilot-scale domestication, which might result in community structure optimization and substrate selective ability improvement of the microbial population.

These findings should be viewed with caution due to the different characteristics of the real acidogenic liquids used for lab or pilot scale PHAs-producing fermentations. As an example, $\mathrm{COD} / \mathrm{NH}_{4}{ }^{+}$ratios were 19 for the hydrolysate employed in the laboratory experiments, 15.68 for the one used at pilot scale, and 20.5 for the simulated acidogenic liquid. Additionally, no information is provided about the composition of the PHAs obtained. In any case, the authors proved that the integration of anaerobic digestion and PHAs fermentation at pilot scale was feasible to reduce excess sludge disposal and produce PHAs with low cost.

Continuing with the study of the scaling process, Morgan-Sagastume et al. [90] evaluated the integrated production of polyhydroxyalkanoates (PHAs) with municipal wastewater and sludge treatment by operating a pilot plant for 22 months. Although this study has already discussed in Effect of Temperature paragraph in Section 3.2.1, it should be recalled that the authors stated that producing a biomass with $0.5 \mathrm{~g}$ PHA/g VSS is considered to be realistically achievable within the typically available carbon flows at municipal waste management facilities.

\subsubsection{Assisted Biological Procedures}

Some authors have also opted to combine the biological hydrolysis of sludge with the addition of different chemicals in order to find potential synergistic effects between them on the PHAs production.

\section{Effect of Additives (Peroxides)}

$\mathrm{Xu}$ et al. [92] studied the feasibility of producing PHAs with calcium peroxide $\left(\mathrm{CaO}_{2}\right)$ treated chemically enhanced primary sedimentation sludge fermentation liquor. With this aim, different $\mathrm{CaO}_{2}$ dosages, ranging from 0.02 to $0.1 \mathrm{~g} \mathrm{CaO}_{2} / \mathrm{g} \mathrm{SS}$, were added to a primary sludge previously thickened by $\mathrm{FeCl}_{3}$ coagulation, observing a significant enhancement in the SCFAs generation during the subsequent acidogenic digestion at $37^{\circ} \mathrm{C}$ and without $\mathrm{pH}$ control, in comparison to the control without $\mathrm{CaO}_{2}$ addition. On the other hand, the release of $\mathrm{P}$ from sludge decreased with increasing $\mathrm{CaO}_{2}$ dosage, which was probably attributed to the precipitation of calcium phosphate. $\mathrm{CaO}_{2}$ also induced the microbial reduction of $\mathrm{Fe}$ (III) and helped to maintain the alkaline conditions, facilitating the sludge disintegration.

Numerically, a $\mathrm{CaO}_{2}$ dosage of a $0.1 \mathrm{~g} / \mathrm{g}$ SS increased the $\mathrm{SCOD}_{\mathrm{o}}$ solubilization by $35 \%$ and the SCFAs yield by $44.7 \%$ compared with the control sludge. It was also proved that the SCFAs yield with $\mathrm{H}_{2} \mathrm{O}_{2}$ treatment was not enhanced as much as $\mathrm{CaO}_{2}$ was, due 
to a serious inhibition of the acidogenic bacteria by $\mathrm{H}_{2} \mathrm{O}_{2}$ at high dosages. $\mathrm{CaO}_{2}$ addition not only changed the proportion of SCFAs but also their distribution by increasing the quantities of propionic acid (48\% with $\mathrm{CaO}_{2}$ and $40 \%$ for control) and lowering the acetic acid ones (36\% with $\mathrm{CaO}_{2}$ and $42 \%$ for control).

It should be noticed that $\mathrm{CaO}_{2}$ addition also decreased $\mathrm{Fe}^{2+}$ concentration, which was toxic for the microbes. Therefore, $\mathrm{CaO}_{2}$ dosage was beneficial to the further utilization of fermentation liquor as a substrate for PHAs biosynthesis due to the reduced concentration of $\mathrm{Fe}^{2+}$. Another advantage is that the release of $\mathrm{P}$ from sludge decreased with the increasing $\mathrm{CaO}_{2}$ dosage, due to the precipitation of calcium phosphate, which was also beneficial to utilize the fermentation liquor as substrate for PHAs production. Utilizing the fermentation liquor obtained with a $\mathrm{CaO}_{2}$ dosage of a $0.1 \mathrm{~g} / \mathrm{g}$ SS as medium, the PHAs content in activated sludge reached $22.3 \%$ after 35 days, which was comparable to those obtained using waste materials as carbon source. PHAs composition was 50\% PHB and $50 \%$ PHV. This did not turn out to be surprising, taking into the high proportion of acids with an odd number of carbon atoms $(57.4 \%)$ in the initial biological hydrolysate.

\section{Effect of Thermal Pretreatment}

This section would include those studies dealing with thermally assisted biological hydrolysis procedures. However, this strategy could also be considered as a biologically assisted thermal hydrolysis. In this basis, the studies focused on these procedures were considered the same, so the reader is referred to Section 3.3.2.

\subsection{Thermal Hydrolysates for PHAs Production}

The aforementioned studies make it clear that biological hydrolysis is a feasible sludge pretreatment to obtain suitable substrates for subsequent PHAs bioproduction. However, there are other available pretreatments to improve the production of PHAs. In this sense, hydrothermal processes can enhance the solubilization, hydrolysis, and SCFAs content of the sludge. This is why, in the following lines, studies involving the hydrothermal pretreatment of sludge in order to enhance SCFAs production and, consequently, PHAs accumulation in a subsequent fermentation, will be revised.

\subsubsection{Non-Assisted Thermal Procedures}

This section includes all those recent studies where thermally hydrolyzed sludge is directly used as substrate for PHAs-producing fermentations, completely avoiding the acidogenic digestion of the sludge.

\section{Effect of Temperature}

In this context, Liao et al. [93] assayed the effect of temperature during thermal pretreatrment of a waste sludge from a secondary sedimentation tank on the subsequent PHAs-producing fermentation. The range of temperature tested was $60-120^{\circ} \mathrm{C}$ and the duration of the pretreatment was $2 \mathrm{~h}$.

Predictably, alongside the increase of heat-pretreatment temperature, SCOD, and concentrations of soluble proteins, carbohydrate, ammonia nitrogen, and SCFAs increased. The maximum solubilization was reached at $100{ }^{\circ} \mathrm{C}$, with final soluble COD and SCFAs concentrations 7.3 and 29 times higher than the initial ones. It is noticeable that temperatures higher than $100^{\circ} \mathrm{C}$ involved a lower solubilization, which was due to the proteins precipitation by conformational changes in their structure.

Nevertheless, the lowest SCFAs /SCOD ratio was also found at $100{ }^{\circ} \mathrm{C}(25.5 \%)$, whereas it increased as the temperature moved away from this value. In fact, $60{ }^{\circ} \mathrm{C}$ was the best value of the tested heat-pretreatment temperature range to improve the PHAs productivity, because the SCFA/SCOD was the highest (55.6\%).

The pretreatment temperature did not only have an effect on the amount but also on the distribution of SCFAs. Results showed that the predominant SCFA in the hydrolysis liquid at $60^{\circ} \mathrm{C}$ was acetic acid, accounting for $47.1 \%$ of total SCFAs, while propionic acid 
was the major component in the hydrolysis liquid at 80,100 , and $120{ }^{\circ} \mathrm{C}(46.0 \%, 53.4 \%$ and $42.2 \%$ for each).

During the PHAs-producing fermentation itself, microorganisms showed a quick adaptation to sludge carbon source at any pretreatment temperature. It was confirmed that $60{ }^{\circ} \mathrm{C}$ was the optimal temperature for the sludge pretreament in terms of PHAs synthesis, with a maximal PHAs content of $24.1 \%$ of dry cell in less than $3 \mathrm{~h}(\approx 14 \%$ for other temperatures). For all the pretreatment temperatures, PHA polymer was mainly composed by $\mathrm{PHB}$, with the highest PHV percentage being observed using $100{ }^{\circ} \mathrm{C}$ hydrolysate $(17.9 \%)$; at this temperature, the highest percentage of odd-numbered SCFAs was found.

\section{Effect of Oxidizing Atmosphere}

Although thermal hydrolysis is clearly the most commonly used non-biological technique to improve PHAs production (either in combination with a subsequent biological hydrolysis or alone), there is another hydrothermal treatment that has also been employed: wet oxidation. This is an oxidative treatment that shares hydrolytic characteristics with thermal hydrolysis, although it adds oxidation reactions due to the presence of pressurized oxygen during the treatment instead of an inert atmosphere, thus being more effective in terms of solubilization [18]. The main advantage of this technique is that it promotes the generation of SCFAs as final products under appropriate conditions, which in turn should improve the subsequent PHAs-producing fermentation.

On this basis, Wijeyekoon et al. [94] employed a wet oxidation pretreatment at $240{ }^{\circ} \mathrm{C}$ and 20 bar for $2.5 \mathrm{~h}$ to obtain a sludge hydrolysate from a mixed sludge. It is interesting to note that prior to the wet oxidation treatment, this sludge was subjected to an acidogenic pre-fermentation, although the characteristics of either this pre-fermentation or the initial sludge were not reported; it was only indicated that wet oxidation was able to remove almost $98 \%$ of the VSS. These authors not only tested the wet oxidation hydrolysate but also same hydrolysate after being subjected to an ammonia stripping process with air, aiming to increase the $\mathrm{C} / \mathrm{N}$ ratio from 4 to 12 . Either the raw or ammonia-stripped hydrolysates showed a SCFAs /TOC ratio of around $46.4 \%$ and were mainly composed of acetic acid $(74.3 \%)$ and propionic acid $(12.5 \%)$.

The results revealed that the maximum PHAs accumulation (40.1\% of the TSS) was reached using ammonia-stripped hydrolysate as substrate and after $7 \mathrm{~h}$ of fermentation at $30^{\circ} \mathrm{C}$. It is interesting to note that non-removal of ammonia slowed down the PHAs production (from 7 to $12 \mathrm{~h}$ ) but not the maximum accumulation (39\%). Ammonia concentration in the hydrolysate did not have a significant effect on the PHAs composition for both hydrolysates, with $76.8 \%$ of the polymer weight being due to PHB and $23.2 \%$ remaining PHV. The authors also found that feeding regimes affected the rate of PHAs accumulation and composition. Equal doses of substrate fed hourly at $25 \%$ DO saturation was found to be the best conditions based on PHAs yield on substrate.

\subsubsection{Assisted Thermal Procedures}

This section collects all those recent studies where thermally hydrolyzed sludge is subsequently subjected to an acidogenic digestion to increase its content in SCFAs before being fed to the PHA-producing fermenter.

The first study with this approach was published by Morgan-Sagastume et al. [95], who used a biologically fermented effluent from a CAMBI process as substrate for a subsequent PHAs-producing fermentation. CAMBI technology refers to a commercial thermal hydrolysis technology. During the CAMBI process, sludge is dewatered and preheated to $100{ }^{\circ} \mathrm{C}$; then, it is subjected to temperatures between 160 and $180{ }^{\circ} \mathrm{C}$ and pressures about 6 bars and finally directed to a flash tank where a sudden temperature and pressure decrease leads to a high cell breakage and solubilization [96].

The CAMBI hydrolysate was later fermented at $42{ }^{\circ} \mathrm{C}$ for 2 days, reaching final SCFAs/SCOD and COD/ $\mathrm{NH}_{4}{ }^{+}$ratios of 0.5 and 10.53, respectively. This biological hy- 
drolysate was rich in acetic acid (27.1\%), butyric acid (23.1\%), propionic acid (17.1\%), iso-valeric acid (17.1\%), caproic acid (7\%), valeric acid (5\%), and iso-butyric acid (3.5\%).

Putting the light on the PHAs production results, the high proportion of non-SCFAs compounds in the substrate (only 50\% of the SCOD was due to SCFAs) tarnished the results of PHAs accumulation, only reaching a yield of $19.5 \%$ (0.195 $\mathrm{g}$ PHA/g TSS), although it is also true that this value was reached after $1.6 \mathrm{~h}$ of cycle, resulting in a reasonably high specific PHAs production rate. PHA polymer was composed of PHB (74\%) and PHV (26\%). Again, following the previously addressed relationship between PHAs composition and the SCFAs number of carbons, acids with an even number of carbon atoms accounted for $61 \%$ of the total SCFAs, so it seems logical that PHA was mainly composed of PHB, as was experimentally observed, representing a higher percentage instead of PHV.

Zhang et al. (2019) also proposed a PHAs-producing process from sludge, which was very similar to the studied one by Morgan-Sagastume et al. [95]. During their study, they compared the SCFAs yields during the acidogenic fermentation under mesophilic $\left(35^{\circ} \mathrm{C}\right)$ and thermophilic $\left(55^{\circ} \mathrm{C}\right)$ temperatures of raw or thermally hydrolyzed sludges. The highest production of SCFAs was found to occur at mesophilic temperatures $\left(35^{\circ} \mathrm{C}\right)$ and with a thermally hydrolyzed sludge, reaching a maximum of $9.63 \mathrm{gCOD}$ SCFAs $_{\text {L }}$. It is important to remark that although the highest concentration of SCFAs was reached under these conditions, the highest SCFAs/SCOD ratio was observed using raw sludge at $35{ }^{\circ} \mathrm{C}$ (SCFAs $/ \mathrm{SCOD}=71.4 \%$ ) and not with the hydrolysate from thermally pretreated sludge at $35{ }^{\circ} \mathrm{C}$ (SCFAs $/ \mathrm{SCOD}=50.2 \%$ ).

Temperature did not have an effect on the SCFAs profile when raw sludge was the substrate, with less than $3 \%$ variation in percentages between experiments. On the other hand, temperature did have an impact on SCFAs distribution with thermally pretreated sludge as substrate for the acidogenic fermentation. In this case, higher fermentation temperatures led to a small increase in the proportions of acetic acid ( $28 \%$ and $33 \%$ for $35{ }^{\circ} \mathrm{C}$ and $\left.55^{\circ} \mathrm{C}\right)$ and a slight decrease in valeric acid $\left(26 \%\right.$ and $21 \%$ for $35{ }^{\circ} \mathrm{C}$ and $\left.55{ }^{\circ} \mathrm{C}\right)$.

Even though it is generally accepted that the higher SCFAs/SCOD ratio, the more favorable the PHAs accumulations, Zhang et al. [97] only selected the hydrolysate with the highest SCFAs concentration (raw sludge at $35^{\circ} \mathrm{C}$ ) but not with the highest SCFAs /SCOD ratio (thermally pretreated sludge at $35{ }^{\circ} \mathrm{C}$ ) for assaying the PHAs bioproduction. This acidified hydrolysate, with a COD/ $\mathrm{NH}_{4}{ }^{+}$ratio of 14.3 , surprisingly, showed butyric acid as the main acid present (30\%), followed by acetic acid $(28 \%)$, valeric acid $(26 \%)$, and propionic acid (16\%). The PHAs fermentation was carried out at $35{ }^{\circ} \mathrm{C}$ and led to a PHAs accumulation of $34.6 \%$ of the dry cell weight after $15 \mathrm{~h}$. PHA polymer was mainly composed of PHB (ranging from $71 \%$ to $76 \%$ of the total PHA mass, depending on the sampling time), whereas PHV only accounted for a maximum of $29 \%$ after $10 \mathrm{~h}$. This is an expected finding, taking into account the prevalence of acids with an even number of carbon atoms $(56.3 \%$ of the total acids) in the medium after the acidogenic fermentation.

\subsection{Other Considerations}

As it has been just seen, there exists a high variance in terms of PHAs yields and compositions, which is likely to be due to the wide range of operation conditions, treatments, and raw sludges employed. Obviously, these facts greatly complicate the comparison of results between different authors. In order to try to facilitate this discussion, a table showing the most relevant parameters affecting the final PHAs content (SCFA/SCOD ratio, $\mathrm{COD} / \mathrm{NH}_{4}{ }^{+}$ratio, percentage of SCFAs with an even number of carbon atoms, and acclimation of biomass) was included (Table 3 ). 
Table 3. Summary of the key characteristics of the hydrolysates and other factors that influence final PHAs production in each work. - Indicates data not available. * authors measured TOC instead of COD.

\begin{tabular}{|c|c|c|c|c|c|c|}
\hline Sludge Employed & SCFA/SCOD Ratio & $\begin{array}{l}\% \text { of Acids with an } \\
\text { Even Number of } \\
\text { Carbon Atoms }\end{array}$ & $\begin{array}{l}\text { COD: } \mathrm{NH}_{4}^{+}: \mathrm{P} \\
\left(\mathrm{COD} / \mathrm{NH}_{4}{ }^{+}\right)\end{array}$ & $\begin{array}{l}\text { Acclimation of } \\
\text { Fermentative } \\
\text { Biomass }\end{array}$ & $\begin{array}{l}\text { \% PHA in Dry Cell } \\
\text { Basis }(\Delta \%) \\
\text { (Time) }\end{array}$ & References \\
\hline $\begin{array}{l}\text { Settled activated } \\
\text { sludge }\end{array}$ & $62 \%$ & $66 \%$ & 1621.2:101.6: (15.96) & Yes & $60 \%(46 \%)(0.5 \mathrm{~h})$ & (Liu et al., 2020) \\
\hline $\begin{array}{l}\text { Sludge from } \\
\text { thickening tank (lab } \\
\text { scale) } \\
\text { Diluted dewatered } \\
\text { sludge (pilot scale) }\end{array}$ & $\begin{array}{l}56 \% \text { (lab. scale) } \\
65 \% \text { (pilot scale) }\end{array}$ & $\begin{array}{l}63 \% \\
66 \%\end{array}$ & $\begin{array}{c}\text { 174.78:9.2:1 (19) } \\
230.46: 14.7: 1(15.68)\end{array}$ & Yes, in both processes & $\begin{array}{c}23.2 \%(-)(36 \mathrm{~h}) \\
59 \%(34 \%)(72 \mathrm{~h} \text { of the } \\
\text { 4th batch) }\end{array}$ & (Jia et al., 2014) \\
\hline $\begin{array}{l}\text { Thickened waste } \\
\text { activated sludge }\end{array}$ & $90 \%$ & $65 \%$ & 100:10:5 (10) & Yes & $38 \%(36 \%)(15 \mathrm{~h})$ & $\begin{array}{c}\text { (Morgan-Sagastume } \\
\text { et al., 2015) }\end{array}$ \\
\hline $\begin{array}{l}\text { Secondary from } \\
\text { sedimentation tank }\end{array}$ & $36 \% *$ & $86 \%$ & 661.3:6.9:1 (95.84)* & No & $56.5 \%(52.5 \%)(3.7 \mathrm{~h})$ & $\begin{array}{l}\text { (Mengmeng et al., } \\
\text { 2009) }\end{array}$ \\
\hline $\begin{array}{c}\text { Chemically enhanced } \\
\left(\mathrm{FeCl}_{3}\right) \text { sedimentation } \\
\text { primary sludge }\end{array}$ & $93.5 \%$ & $42.6 \%$ & 269:13.5:1 (19.93) & No & $\begin{array}{c}22.3 \% \text { (after } 32 \mathrm{~d}) \\
18 \%(13 \%)(0.375 \mathrm{~h} \text { of } \\
\text { cycle })\end{array}$ & (Xu et al., 2018) \\
\hline $\begin{array}{c}\text { Thermally } \\
\text { hydrolyzed primary + } \\
\text { municipal waste } \\
\text { activated sludge }\end{array}$ & $49.75 \%$ & $61 \%$ & $200: 19: 3(10.53)$ & Yes & $\begin{array}{c}19.5 \%(\text { after } 75 \mathrm{~d}) \\
19.5 \%(4 \%)(1.6 \mathrm{~h} \text { of } \\
\text { the cycle })\end{array}$ & $\begin{array}{l}\text { (Morgan-Sagastume } \\
\text { et al., 2010) }\end{array}$ \\
\hline $\begin{array}{c}\text { Primary + secondary } \\
\text { sludge }\end{array}$ & $50.2 \%$ & $57.4 \%$ & 418.1:29.3:1 (14.3) & No & $34.6 \%(28.6 \%)(15 \mathrm{~h})$ & (Zhang et al., 2019) \\
\hline $\begin{array}{l}\text { Secondary from } \\
\text { sedimentation tank }\end{array}$ & $55.4 \%$ & $56.3 \%$ & 977.5:66:- (14.72) & Yes & $24.1 \%(11.6 \%)(1.5 \mathrm{~h})$ & (Liao et al., 2018) \\
\hline $\begin{array}{l}\text { Mix of primary and } \\
\text { waste-activated } \\
\text { sludge with } \\
\text { acidogenic } \\
\text { fermentation }\end{array}$ & $46.3 \%$ * & $85.1 \%$ & $47: 3.92: 1(12) *$ & Yes & $40.1 \%(39.1 \%)(7 \mathrm{~h})$ & $\begin{array}{c}\text { (Wijeyekoon et al., } \\
\text { 2018) }\end{array}$ \\
\hline
\end{tabular}




\subsubsection{Sludge Characteristics}

It is interesting to notice from Table 3 that many authors selected secondary activated sludges as starting materials $[85,86,90,91,93]$. These sludges, which were typically withdrawn from the sedimentation tank of a WWTP, showed TSS concentrations ranging from 4.5 to $13.1 \mathrm{~g} / \mathrm{L}[89,91,93]$. Other authors opted for more dewatered sludges with solid concentration between 30 and $43 \mathrm{~g}$ TSS/L [85,90].

The use of mixtures of primary and secondary sludges was less common, with solid contents ranging from 24 and $46 \mathrm{~g}$ VS/L [94,95,97]. Curiously, this combination was selected as the influent of thermal hydrolysis processes, whose hydrolysates were latterly the substrates of the PHAs production operations. Finally, only Xu et al. [92] used a primary sludge (5.7 gTSS/L) as the starting material.

\subsubsection{Hydrolysate Characteristics}

Focusing now on the hydrolysis method employed as pretreatment before the PHAproducing fermentation, anaerobic digestions were the predominant ones $[85,89,90]$, followed by thermal hydrolysis $[93,95,97]$. Paying attention to biological hydrolysis, typical conditions to generate the SCFAs that will be later transformed into PHAs include temperatures ranging from 36 to $60^{\circ} \mathrm{C}$ with or without $\mathrm{pH}$ adjustment. It should be noticed that even when it was addressed that alkaline $\mathrm{pH}$ values yielded more SCFAs in the previous section (see Section 2), it seems that this parameter did not have much relevance in comparison to SCFAs/COD ratios in terms of PHAs production. In this regard, SCFAs/COD ratios for sludge hydrolysates from acidogenic fermentation typically ranged from $55.83 \%$ to $65 \%$ [81,82]. The high SCFAs/COD ratio (90\%) reported by Morgan-Sagastume et al. [90] is surprising, which is probably due to the lack of a primary waste sludge treatment in the WWTP, according to the authors.

For its part, the proportion of acids with an even number of carbon atoms in biological hydrolysates usually slightly oscillates among studies, from $63 \%$ to $66 \%$, regardless of the conditions of treatment and the initial sludge characteristics. The results suggest that the SCFAs/COD ratio can be increased by adding chemicals before the acidogenic fermentation, such as $\mathrm{CaO}_{2}$ or SDBS.

Moving on to the hydrothermal treatments as pretreatment for biological acidification, the final hydrolysate had a lower SCFAs/COD ratio than the one obtained by only employing biological treatments $[95,97]$. Nevertheless, the feeding in these cases included primary sludges, whereas secondary sludges were employed in the studies with only biological acidification, so the effect of the thermal pretreatment could be compromised by the presence of the primary sludges. In any case, during the use of thermal treatments either as pretreatment or sole treatment to obtain the hydrolysate, the composition of the SCFAs showed little reduction on the proportion of acids with an even number of carbons, also if primary sludge was not present in the feeding ( $57.4 \%$ and $61 \%$ versus $56.3 \%)$. These values were lower to those obtained for acidogenic fermentations without thermal pretreatments.

The selection of hydrothermal treatments, either as the sole hydrolysis method or as pretreatment for a subsequent acidogenic digestion, also reduced the final PHAs production, not only provoking a lower SCFAs/COD ratios in the hydrolysate but also reducing the microbial growth due to the generation of inhibitory compounds during the treatment [18]. Nevertheless, these drawbacks can be avoided by means of the presence of oxygen during the hydrothermal treatment. Thus, wet oxidation promoted the generation of SCFAs and reduced the formation of inhibitory products such as HMF or phenolic derivatives $[45,98]$. However, these statements need further research to be confirmed.

\subsubsection{PHA Effluent Characteristics}

Concerning the generation of PHAs itself using the hydrolysates obtained, initial inoculum usually consists of microorganisms from the activated sludge of the WWTP which are cultivated in an sequencing batch reactor (SBR) with a feast-famine strategy 
in cycles, using as feed real hydrolysates or, to a lesser extent, synthetic hydrolysates. However, some authors decided to use non-acclimated inocula directly $[91,92,97]$.

Although it is extremely difficult to establish comparisons between different studies due to the high heterogeneity of conditions during both SCFAs and PHAs generations, results suggest that the prior acclimation of the PHA-producing inoculum is not a determining factor for increasing the final PHAs accumulation at the end of the fermentation. As an example, Mengmeng et al. [91] reported a 56.5\% of PHAs accumulation on a dry cell basis directly using raw sludge to inoculate the fermenter, whereas Jia et al. [85] or Liao et al. [93] achieved lower yields, $23.2 \%$ and $24.1 \%$ of PHAs, respectively, even when they used a previously acclimated sludge.

It is also difficult to establish a pattern of the effects of the hydrolysate sludge composition on the final PHAs accumulation by microorganisms, again attending to the high heterogeneity in operating conditions and raw sludge characteristics. The results from Table 3 suggest that the PHAs production is favored by sludge hydrolysates rich in SCFAs. However, when comparing the works of Liu et al. [89] and Morgan-Sagastume et al. [90], both showing similarities in either the initial sludge or the hydrolysis method (biological hydrolysis), it can be deduced that an excessively high SCFAs/COD ratio can have a negative impact on PHAs bioproduction.

More specifically, Liu et al. [89] reported a SCFAs/COD ratio of $62 \%$ and the maximum PHAs accumulation of 60\%. Meanwhile, Morgan-Sagastume et al. [90], with a SCFAs/COD ratio of $90 \%$, observed a final PHAs content in the biomass of only $38 \%$. In the same way, $\mathrm{Xu}$ et al. [92] also observed a low PHAs yield (18\%) using a sludge hydrolysate with a high SCFAs /COD ratio (93.5\%). Therefore, SCFAs/COD ratios higher than $90 \%$ hinder the PHAs production. At the same time, more than $30 \%$ of non-SCFAs in the feeding reduces the final PHAs production. Therefore, it can be concluded that the highest PHAs accumulation can be obtained for SCFAs/COD ratios around $60-70 \%$. At higher ratios, SCFAs inhibited the bacterial growth, whereas low ratios caused an excessive cell proliferation and no accumulation of PHAs, which only takes place under nutrient-limiting conditions.

Additionally, nutrients as nitrogen also played an important role during the PHAsproducing fermentation. According to Table 3, too low or too high COD $/ \mathrm{NH}_{4}{ }^{+}$ratios in the sludge hydrolysates had a negative impact on PHAs production, observing maximum PHAs accumulations for ratios around 16.

Finally, the last but not least parameter of the hydrolysate composition that played an important role on the final PHAs production is the percentage of acids with an even number of carbon atoms. This is in line with the reported preferential uptake of these SCFAs by microorganisms during PHAs production. As can be deduced from Table 3, a higher percentage of these SCFAs in the sludge hydrolysate is usually linked to a higher PHAs accumulation by microorganisms, as long as the SCFAs/COD ratio was not higher than $90 \%$, as previously discussed. For instance, the best PHAs yields corresponded to those hydrolysates with a higher proportion of acids with an even number of carbon atoms, which is the case of the works of Liu et al. [89], Jia et al. [85], Mengmeng et al. [91], and Wijeyekoon et al. [94]. In these studies, where even-numbered SCFAs predominate $(66 \%$, $66 \%, 86 \%$, and $85.1 \%$, respectively), the final PHAs content was among the highest reported $(60 \%, 59 \%, 56.5 \%$, and $40.1 \%)$.

\section{Other Metabolites}

As seen in previous sections, sewage sludge hydrolysates are a powerful substrate to obtain added-value products that could improve the sludge reuse during its management and introduce WWTPs in the circular economy. Despite having been the subject of many in-depth studies for the last few years, SCFAs and PHAs are not the one and only products that could be obtained from sludge hydrolysates by fermentation. Other metabolites with higher molecular weights, such as enzymes or lipids, can also be obtained from sludge by selecting adequate microorganisms and operation conditions during either its hydrolysis pretreatment or the subsequent fermentation process. Using sludge hydrolysates for 
the production of these metabolites involves significant industrial savings, since typical fermentation media for these kind of processes account for $30-40 \%$ of the total production cost [99], whereas sludge is a cheap and ubiquitous waste.

However, as will be checked, these are still low explored alternatives, even though they represent a very attractive renewable source of high-value products.

\subsection{Enzymes}

\subsubsection{General Considerations}

As proteases and laccases are the enzymes whose production will be here described, their applications will be cited. These have been extracted from the reviews of Razzaq et al. [100] and Rodríguez Couto and Toca Herrera, [101].

Proteases are commonly used enzymes in several fields. For example, they are widely spread in detergents. They are also used to facilitate the chemical synthesis of organics from amino acids. Textile applications include the degumming of silk or the dehairing of leather. Their role in the food industry is related to the production of bioactive peptides or hydrolysates with antioxidant activity or the improvement in dough properties by gluten breakage and in cheese manufacturing. Proteases have also been applied in the decontamination of wastewaters that contain hair or feathers as well.

Regarding laccases uses, they have been employed in the wood and paper industry for bleaching and pulping, as well as in the decontamination of effluents. Their capability of degrading phenolic compounds makes them useful for the decontamination of wastewaters from textile industries. Laccases can also be applied in the food industry for the elimination of colored phenols from beverages and to produce crosslinking for more resistant and less elastic doughs. They also have cosmetic applications, for example in the manufacturing of hair dyes.

Putting firstly the focus on enzyme production, proteases are probably the most promising candidate to be obtained from sludge hydrolysates, attending to their composition. In this sense, proteins are largely the most abundant biopolymer in the sludge, nearing $60 \%$ [102]. Thus, sludge hydrolysates can be used as potential fermentation media for microorganisms with a significant proteolytic enzymatic activity. Proteases production is a matter of great interest, since these enzymes are responsible for almost $60 \%$ of the enzyme market [103]. Among the microorganisms available for this purpose, Bacillus species are known to be proteolytic and profusely producers of proteases such as subtilisin or alkaline proteases [103-105].

\subsubsection{Production}

The inoculation of Bacillus in sewage sludge hydrolysates with the aim of producing proteases was firstly studied by Drouin et al. [106], paying special attention to the effect of the sludge hydrolysis pretreatments on the final protease yields. The hydrolysis methods consisted of an alkaline thermal hydrolysis at $\mathrm{pH} 10$ and at two different temperatures (121 and $140^{\circ} \mathrm{C}$ ) for $30 \mathrm{~min}$. The authors also carried out fermentations using the raw secondary sludge and the hydrolysate obtained at $140{ }^{\circ} \mathrm{C}$ mixed with raw sludge $(1: 1)$ as substrates. In each case, Bacillus licheniformis was inoculated during its exponential growth phase, with the fermentation being carried out at $35^{\circ} \mathrm{C}$ for $48 \mathrm{~h}$ and keeping the $\mathrm{pH}$ controlled and fitted to 7.5, which was the optimal value for the microorganism development.

Results showed that mixing raw sludge and thermo-alkaline hydrolysate $\left(140{ }^{\circ} \mathrm{C}\right)$ promoted the highest protease activity at the end of the fermentation, whereas the lowest protease activity was reported employing only thermo-alkaline-treated sludge as the fermentation medium. This fact was attributed by the authors to a high viscosity in the thermo-alkaline hydrolysate that made oxygen transfer difficult. Nevertheless, the difference in proteolytic activities was approximately of only 3 units (from $13.0 \mathrm{U} / \mathrm{mL}$ for the mixture to $9.8 \mathrm{U} / \mathrm{mL}$ for the thermo-alkaline hydrolysate). When in situ hydrolyzed sludge or raw sludge were employed as growth media for B. licheniformis, similar proteolytic activities were reported, $11.5 \mathrm{U} / \mathrm{mL}$ or $10.4 \mathrm{U} / \mathrm{mL}$, respectively. 
These activity values seem very low, especially in the comparison of hydrolysates with raw sludge. As the authors reported, viscosity could harm the oxygen transfer. Moreover, as mentioned in the Introduction, hydrothermal treatments could generate inhibitors to microbial growth that also led to the poor results observed.

Recent research dealing with enzymes production from sludge hydrolysates include not only proteases but also laccases recovery. The simultaneous production of both protease and laccase enzymes was reported by García et al., currently pending of publication [107] by means of the growth of $B$. licheniformis in thermally hydrolyzed secondary sludge. In this study, the authors compared the employment of thermal hydrolysates obtained in the presence (wet oxidation) or absence (thermal hydrolysis) of an oxidizing atmosphere as fermentation media for B. licheniformis. Both treatments were carried out at $160{ }^{\circ} \mathrm{C}$ and 40 bar of oxygen or nitrogen for $70 \mathrm{~min}$, aiming not to completely destroy the biopolymers present in the sludge. Afterwards, B. licheniformis was inoculated in the hydrolysates, which were already sterilized after the thermal treatment. The fermentation was carried out at $37^{\circ} \mathrm{C}$, with an initial $\mathrm{pH}$ adjusted to 7.2 . Moreover, the authors also evaluated the $B$. licheniformis fermentation of either diluted hydrolysates (1:1) or in a synthetic hydrolysate, to investigate the potential generation of toxics during the hydrothermal treatment and to provide a basis of comparison, respectively.

Results showed that $B$. licheniformis was able to grow in both hydrolysates. In the case of the wet oxidation, it did it better in the diluted hydrolysate, which was probably due to the formation of toxics during the oxidizing treatment, such as furfurals. Regarding biopolymers evolution in the thermal hydrolysis liquid, B. licheniformis firstly consumed carbohydrates, followed by proteins and finally humic acids, which were only degraded when the stationary growth phase was reached $(96 \mathrm{~h})$. Similar trends were observed when the diluted hydrolysate obtained in the absence of oxygen was employed as substrate. In the case of the wet oxidation hydrolysates, diluted or not, the sequential uptake behavior was more marked. It is interesting to note that the initial carbohydrates uptake using the wet oxidation hydrolysates was higher than selecting the thermal hydrolysis hydrolysates, which was probably due to the greater solubilization provided by oxidizing atmospheres. In turn, proteins from wet oxidation hydrolysate were less consumed and only metabolized during the stationary phase; this phenomenon was attributed to the higher damage caused by oxidation reactions. The humic acid's behavior was similar to that reported for protein.

Regarding the activities of proteases and laccases, the production of the former was almost doubled during the fermentation of the thermal hydrolysis liquid in comparison to the wet oxidation one (898 and $495 \mathrm{U} / \mathrm{mL}$, respectively). For both hydrolysates, proteases were mainly generated during the stationary growth phase, coinciding with the most intense protein uptake $(72 \mathrm{~h}$ in the case of the thermal hydrolysis and 120 in the case of the wet oxidation). The effect of dilution on the protease activity was in line with the expectations, halving the maximum protease activity and demonstrating that the potential toxic compounds did not affect protease activity at the same time. On the other hand, focusing on laccase production, this was much lower for the thermal hydrolysis hydrolysate than for the wet oxidation one (28.8 U/OD at the end of the experiment and $55 \mathrm{U} / \mathrm{OD}$ after only $72 \mathrm{~h}$ with final values in a rising trend), which was probably due to an easier assimilation of proteins from hydrolysates obtained under inert atmospheres, in contrast with the oxidizing ones, thus not requiring to produce its laccases to start the metabolization of humic acids.

The dilution of hydrolysates strongly affected laccase production but in different trends. For the fermentation carried out with thermal hydrolysis effluent previously diluted, final laccase activity was almost negligible, whereas using diluted wet oxidation hydrolysate, laccases production was strongly enhanced, reaching values higher than 50 $\mathrm{U} / \mathrm{OD}$ in the first $24 \mathrm{~h}$, although it decreased until the end of the experiment.

Finally, the authors also employed a synthetic hydrolysate with similar concentrations of biopolymers to those found in the real hydrolysates tested. In this medium, $B$. licheniformis was able to at least double its growth in comparison to the previously reported 
for real hydrolysates. The consumption of biopolymers in synthetic media corroborated the preferential uptake of carbohydrates, especially the reducing ones, as was addressed for the real hydrolysates. The authors also reported a strong uptake of proteins when carbohydrate consumption was less intense.

Despite the high biopolymer uptake, enzymatic activity behavior did not show significant differences to that found in the real hydrolysates when glucose was used as a carbohydrate model. Nevertheless, the use of starch as reference highly increased the production of either proteases or laccases. According to the authors, this increase in enzymes production in the presence of complex carbohydrates is attributed to lower bioassimilation of these by the bacteria, forcing them to use other carbon sources, such as proteins and carbohydrates. The authors concluded that although results obtained from real hydrolysates were promising, there is still a lot of work to be done to improve the production of enzymes in sludge hydrolysates-for example, optimizing both hydrolysis and cultivation conditions, as well as exploring the microorganisms that could produce high quantities of enzymes.

\subsection{Lipids}

\subsubsection{General Considerations}

Moving now to the applications of lipids, these include mainly the production of oleochemicals. Examples of these are fatty alcohols, which have been used in detergents, biofuels, or cosmetics. Moreover, they can be employed as substrates for the synthesis of rhamnolipids, sophorolipids, and n-acetylethanolamines. Rhamnolipids and sophorolipids are biosurfactants, whereas n-acetylethanolamines are used in pharmaceutical synthesis. However, the main application of lipids is the synthesis of biodiesel [30].

\subsubsection{Production}

Liu et al. [108] employed several pretreatments to obtain a final hydrolysate suitable to be used as growth medium for an oleaginous yeast, Cryptococcus curvatus ATCC 20509. Firstly, they subjected a dewatered secondary sludge (VSS $=5 \mathrm{~g} / \mathrm{L}$ ) to a thermal alkaline hydrolysis at $90^{\circ} \mathrm{C}$ and $\mathrm{pH} 10$ for $6 \mathrm{~h}$. Then, the hydrolysate obtained was anaerobically fermented at $\mathrm{pH} 8$ for 10 days to produce a medium rich in SCFAs, especially in acetic (almost $3.5 \mathrm{~g} / \mathrm{L}$ ) and propionic acids $(1.6 \mathrm{~g} / \mathrm{L}$ ), and with low concentrations of iso-butyric, $\mathrm{n}$-butyric, and valeric acids $(0.77,0.75$, and $0.85 \mathrm{~g} / \mathrm{L}$, respectively). Afterwards, the fermentation broth obtained was subjected to two different treatments: a struvite precipitation and a struvite precipitation plus an acid separation. The authors included these steps to increase the $\mathrm{C} / \mathrm{N}$ ratio, whose initial value was 10 . By means of the former, struvite precipitation, inorganic ammonia was removed, raising the $\mathrm{C} / \mathrm{N}$ ratio to 60 . With the second treatment, struvite precipitation plus acid separation, inorganic ammonia, and proteins were removed, which resulted in raising the $\mathrm{C} / \mathrm{N}$ ratio to 111 .

These effluents with different $\mathrm{C} / \mathrm{N}$ ratios were subsequently fermented by Cryptococcus curvatus ATCC 20509, in a sequencing batch reactor at $30^{\circ} \mathrm{C}$. This reactor was periodically fed, replacing the medium by fresh hydrolysate when the yeast reached the stationary growth phase.

Lipid accumulation by the yeast showed results of $1.11 \mathrm{~g} / \mathrm{L}$ ( $0.155 \mathrm{~g}$ lipid/g biomass) using the liquid obtained after struvite precipitation. This value, which was under the authors expectations, was attributed to a low $\mathrm{C} / \mathrm{N}$ ratio. Nevertheless, the introduction of an acid precipitation step allowed to increase the $\mathrm{C} / \mathrm{N}$ ratio more but not the production of lipids, which was around $0.98 \mathrm{~g} / \mathrm{L}$ ( $0.31 \mathrm{~g}$ lipid/g biomass). In this case, the authors suggested that the low lipid yield was yet caused by an excess of organics, such as proteins, carbohydrates, or humic acids. This was the reason why the authors decided added a third separation step, a coagulation step with poly-aluminum chloride, prior to struvite precipitation and acid separation.

The combination of these three treatments did not change to a great extent the $\mathrm{C} / \mathrm{N}$ ratio achieved with only struvite precipitation and acid separation with coagulation, but it 
significantly increased lipid accumulation to $1.95 \mathrm{~g} / \mathrm{L}$ ( $0.397 \mathrm{~g}$ lipid/g biomass). This yield was 2.56 times higher than the one achieved with only struvite precipitation and 1.28 times higher than the content reported with struvite precipitation and acid separation.

\section{Conclusions and Future Outlook}

It has been shown that hydrolyzed sewage sludge is a very promising fermentation medium for the bioproduction of added-value, non-energy molecules. The main limiting step of this approach is a proper solubilization and hydrolysis of the sludge in order to improve the bioassimilation of nutrients by the corresponding microorganism. To this end, biological and/or thermal pretreaments are the options more profusely employed by researchers.

In the literature, the bioproduction of SCFAs has been well studied due to their wide range of industrial applications. This SCFAs bioproduction from sludge consists mainly of conventional anaerobic digestions in which the methanogenic microorganisms are inhibited. Therefore, biological hydrolysis and SCFAs generation processes are coupled, and an inoculation is not required. In this sense, $\mathrm{pH}$ plays a key role, with alkaline $\mathrm{pHs}$ speeding up the sludge solubilization and, at the same time, inhibiting the methanogenic population. However, a strongly alkaline biological hydrolysis led to higher solubilizations as well as the release of compounds refractory to biological transformation, reducing the final SCFAs/SCOD ratio. The purity of SCFAs in the fermented liquid was also improved when $\mathrm{pH}$ was only initially adjusted to alkaline $\mathrm{pH}$ instead of keeping it continuously controlled during the whole fermentation. Moreover, increasing the $\mathrm{pH}$ provoked a decrease in propionic acid proportion but favored the butyric and valeric acids ones in the SCFAs profiles.

SCFAs distribution was also related to solubilization degree, since when more proteins were present, a higher proportion of butyric and valeric acids were synthesized by the microorganisms. It was found that an excessive OLR caused the overload of the substrate as well as to the accumulation of heavy metals and other inhibitory compounds, decreasing the production of SCFAs. The initial inoculation of the sludge boosted the SCFAs generation and modified its profile. Results revealed that the higher the inoculum size, the lower either the SCFAs accumulation or the production of long-chain fatty acids.

Biological hydrolysis can be also improved by adding CER, sand, or oxidants during fermentation, although an excessive dosage of these had a negative impact on the SCFAs generation.

The initial stages of solubilization and hydrolysis of sludge can be also carried out separately from the biological production of SCFAs by chemical or thermal or pretreatments. Focusing on the former, the dosage of $\mathrm{CaO}$ generated hydroxy radicals, which promoted the dissolution of flocs, and, at the same time, $\mathrm{Ca}^{2+}$ affected the sludge floc structure via bonding with functional groups, thus also improving the solubilization and the generation of butyric and valeric acids. In a similar way, adding SDBS to sludge improved the production of SCFAs, favoring the production of acetic acid and n-butyric acid in comparison to the propionic acid.

Thermal pretreatments also increased the SCFAs bioproduction and the proportions of propionic, iso-butyric, n-butyric, iso-valeric, and n-valeric acids, although a subsequent inoculation of the hydrolysate was always mandatory. In this regard, the higher the S/I ratio, the higher the SCFAs accumulation but lower their purity in the effluent after the fermentation of the thermally hydrolyzed sludge. The combination of chemical (SDBS) and thermal pretreaments was highly effective in terms of acidogenic potential of the hydrolysate obtained.

The productions of SCFAs and PHAs are highly interconnected because the former are the main substrate for PHAs-producing microorganisms. Taking into account that the SCFAs content in raw sludge is low, a previous sludge acidogenic fermentation is required to boost the PHAs production, although other non-biological pretreatments are also possible for this purpose. This also explains why findings previously explained for 
SCFAs production from sludge are also valid for PHAs. Nevertheless, there exists a high variance in terms of PHAs yields and compositions, which is likely to be due to the wide range of operation conditions, treatments, and raw sludges employed. Obviously, these facts greatly complicate the comparison of results between different authors.

The proportion of acids with an even number of carbon atoms in biological hydrolysates usually slightly oscillate among studies, from $63 \%$ to $66 \%$, regardless of the conditions of treatment and the initial sludge characteristics. Results suggest that the SCFAs/COD ratio can be increased by adding chemicals before the acidogenic fermentation, such as $\mathrm{CaO}_{2}$ or SDBS, or employing thermal pretreatments. The prior acclimation of the PHAs-producing inoculum was not a determining factor for increasing the final PHAs accumulation at the end of the fermentation. It can be concluded that the highest PHAs accumulation can be obtained for sludge hydrolysates with SCFAs/COD ratios around $60-70 \%, \mathrm{COD} / \mathrm{NH}_{4}{ }^{+}$ratios around 16 , and with even-numbered SCFAs predominating.

Despite having been the subject of many in-depth studies for last years, SCFAs and PHAs are not the one and only products that could be obtained from sludge hydrolysates by fermentation. Other metabolites with higher molecular weights, such as enzymes or lipids, can also be obtained from sludge by selecting adequate microorganisms and operation conditions during either its hydrolysis pretreatment or the subsequent fermentation process. In this regard, Bacillus licheniformis was able to properly develop using sludge raw hydrolysates as substrate, with any kind of nutrient supplementation, sterilization, or previous dilution, to produce either proteases or laccases, although the presence of oxygen during the hydrothermal treatment promoted the formation of inhibitory substances. Cryptococcus curvatus can also use thermally hydrolyzed sludge as growth medium to produce lipids, although combined conditioning processes were required to increase productivities.

Future research about the use of sludge hydrolysates as fermentation media should look deeper into the development of new fermentative processes using pure cultures. This approach would allow obtaining non-energy metabolites with a higher added value than SCFAs, such as enzymes, lipids, proteins, etc. The coupling of these processes with a previous thermal pretreatment of the sludge shows some positive synergies, such as higher capacities than biological or chemical pretreatments, the production of a stabilized sludge, the insolubilization of heavy metals during the pretreatment, or the direct inoculation of the hydrolysate, without requiring a previous sterilization. A lot of work stills remain ahead to be done, such as testing different microorganisms or even by incorporating genetic engineering tools. Clearly, another factor to be taken into account in future research should be the downstream processing of the fermentation effluent to ensure either production volume or specification compliance for the product recovered.

Author Contributions: Conceptualization: M.G., S.C. and P.O.; Investigation: M.G. and S.C.; Writing (original draft preparation): M.G. and S.C.; Writing-review and editing: S.C., P.O. and M.D.; Visualization: M.G. and S.C.; Project administration: M.D.; Funding acquisition: M.D. All authors have read and agreed to the published version of the manuscript.

Funding: This research has received external funding from Spanish Ministry of Science, Innovation and University through project MCIU-19-RTI2018-094218-B-I00.

Institutional Review Board Statement: Not applicable.

Informed Consent Statement: Not applicable.

Acknowledgments: The authors would like to thank the financial support from the Ministry of Science, Innovation, and Universities from Spain through the project MCIU-19-RTI2018-094218-B-I00.

Conflicts of Interest: The authors declare no conflict of interest. 


\section{References}

1. Andreoli, C.V.; Sperling, M.V.; Fernandes, F.; Ronteltap, M. Sludge Treatment and Disposal; IWA Publishing: London, UK, 2007; ISBN 978-1-84339-166-1.

2. Eurostat. Sewage Sludge Production and Disposal from Urban Wastewater. Available online: https://ec.europa.eu/eurostat/ tgm/table.do? tab=table\&init=1\&language $=$ en \&pcode $=$ ten $00030 \&$ plugin $=1$ (accessed on 2 December 2020).

3. Cao, B.; Zhang, T.; Zhang, W.; Wang, D. Enhanced Technology Based for Sewage Sludge Deep Dewatering: A Critical Review. Water Res. 2021, 189, 116650. [CrossRef] [PubMed]

4. Raheem, A.; Sikarwar, V.S.; He, J.; Dastyar, W.; Dionysiou, D.D.; Wang, W.; Zhao, M. Opportunities and Challenges in Sustainable Treatment and Resource Reuse of Sewage Sludge: A Review. Chem. Eng. J. 2018, 337, 616-641. [CrossRef]

5. Kor-Bicakci, G.; Eskicioglu, C. Recent Developments on Thermal Municipal Sludge Pretreatment Technologies for Enhanced Anaerobic Digestion. Renew. Sustain. Energy Rev. 2019, 110, 423-443. [CrossRef]

6. Xu, Y.; Lu, Y.; Zheng, L.; Wang, Z.; Dai, X. Perspective on Enhancing the Anaerobic Digestion of Waste Activated Sludge. J. Hazard. Mater. 2020, 389, 121847. [CrossRef] [PubMed]

7. Gao, N.; Kamran, K.; Quan, C.; Williams, P.T. Thermochemical Conversion of Sewage Sludge: A Critical Review. Prog. Energy Combust. Sci. 2020, 79, 100843. [CrossRef]

8. Sena, M.; Hicks, A. Life Cycle Assessment Review of Struvite Precipitation in Wastewater Treatment. Resour. Conserv. Recycl. 2018, 139, 194-204. [CrossRef]

9. Gonzalez, A.; Hendriks, A.T.W.M.; van Lier, J.B.; de Kreuk, M. Pre-Treatments to Enhance the Biodegradability of Waste Activated Sludge: Elucidating the Rate Limiting Step. Biotechnol. Adv. 2018, 36, 1434-1469. [CrossRef] [PubMed]

10. Suárez-Iglesias, O.; Urrea, J.L.; Oulego, P.; Collado, S.; Díaz, M. Valuable Compounds from Sewage Sludge by Thermal Hydrolysis and Wet Oxidation. A Review. Sci. Total Environ. 2017, 584-585, 921-934. [CrossRef] [PubMed]

11. Wu, B.; Dai, X.; Chai, X. Critical Review on Dewatering of Sewage Sludge: Influential Mechanism, Conditioning Technologies and Implications to Sludge Re-Utilizations. Water Res. 2020, 180, 115912. [CrossRef] [PubMed]

12. Gherghel, A.; Teodosiu, C.; De Gisi, S. A Review on Wastewater Sludge Valorisation and Its Challenges in the Context of Circular Economy. J. Clean. Prod. 2019, 228, 244-263. [CrossRef]

13. Moretto, G.; Russo, I.; Bolzonella, D.; Pavan, P.; Majone, M.; Valentino, F. An Urban Biorefinery for Food Waste and Biological Sludge Conversion into Polyhydroxyalkanoates and Biogas. Water Res. 2020, 170, 115371. [CrossRef]

14. Venkata Mohan, S.; Nikhil, G.N.; Chiranjeevi, P.; Nagendranatha Reddy, C.; Rohit, M.V.; Kumar, A.N.; Sarkar, O. Waste Biorefinery Models towards Sustainable Circular Bioeconomy: Critical Review and Future Perspectives. Bioresour. Technol. 2016, 215 , 2-12. [CrossRef] [PubMed]

15. European Commision. European Union: European Commision, Communication from the Commission to the European Parliament, the Council, the European Economic and social Committee and the Committee of the Regions a New Circular Economy Action Plan for a Cleaner and More Competitive Europe, COM/2020/98 Final. 2020. Available online: https: / / eur-lex.europa.eu/legal-content/EN/ALL/?uri=COM:2020:98:FIN (accessed on 2 December 2020).

16. Song, X.; Shi, Z.; Li, X.; Wang, X.; Ren, Y. Fate of Proteins of Waste Activated Sludge during Thermal Alkali Pretreatment in Terms of Sludge Protein Recovery. Front. Environ. Sci. Eng. 2019, 13, 25. [CrossRef]

17. Chatterjee, B.; Mazumder, D. Role of Stage-Separation in the Ubiquitous Development of Anaerobic Digestion of Organic Fraction of Municipal Solid Waste: A Critical Review. Renew. Sustain. Energy Rev. 2019, 104, 439-469. [CrossRef]

18. Hii, K.; Baroutian, S.; Parthasarathy, R.; Gapes, D.J.; Eshtiaghi, N. A Review of Wet Air Oxidation and Thermal Hydrolysis Technologies in Sludge Treatment. Bioresour. Technol. 2014, 155, 289-299. [CrossRef]

19. Appels, L.; Baeyens, J.; Degrève, J.; Dewil, R. Principles and Potential of the Anaerobic Digestion of Waste-Activated Sludge. Prog. Energy Combust. Sci. 2008, 34, 755-781. [CrossRef]

20. Pang, H.; Li, L.; He, J.; Yan, Z.; Ma, Y.; Nan, J.; Liu, Y. New Insight into Enhanced Production of Short-Chain Fatty Acids from Waste Activated Sludge by Cation Exchange Resin-Induced Hydrolysis. Chem. Eng. J. 2020, 388, 124235. [CrossRef]

21. Le, N.T.; Julcour-Lebigue, C.; Delmas, H. An Executive Review of Sludge Pretreatment by Sonication. J. Environ. Sci. 2015, 37, 139-153. [CrossRef] [PubMed]

22. Shehadul Islam, M.; Aryasomayajula, A.; Selvaganapathy, P.R. A Review on Macroscale and Microscale Cell Lysis Methods Micromachines 2017, 8, 83. [CrossRef]

23. Massanet-Nicolau, J.; Dinsdale, R.; Guwy, A. Hydrogen Production from Sewage Sludge Using Mixed Microflora Inoculum: Effect of PH and Enzymatic Pretreatment. Bioresour. Technol. 2008, 99, 6325-6331. [CrossRef] [PubMed]

24. Adamczyk, B.; Smolander, A.; Kitunen, V.; Godlewski, M. Proteins as Nitrogen Source for Plants. Plant. Signal. Behav 2010, 5 , 817-819. [CrossRef]

25. Jones, A.; Mandal, A.; Sharma, S. Protein-Based Bioplastics and Their Antibacterial Potential. J. Appl. Polym. Sci. 2015, 132. [CrossRef]

26. Skeist, I. (Ed.) Handbook of Adhesives, 3rd ed.; Springer: New York, NY, USA, 1990; ISBN 978-1-4612-8019-4.

27. Somanathan, N.; Naresh, M.D.; Arumugam, V.; Ranganathan, T.S.; Sanjeevi, R. Mechanical Properties of Alkali Treated Casein Films. Polym. J. 1992, 24, 603-611. [CrossRef]

28. Tian, H.; Guo, G.; Fu, X.; Yao, Y.; Yuan, L.; Xiang, A. Fabrication, Properties and Applications of Soy-Protein-Based Materials: A Review. Int. J. Biol. Macromol. 2018, 120, 475-490. [CrossRef] 
29. Salati, S.; Papa, G.; Adani, F. Perspective on the Use of Humic Acids from Biomass as Natural Surfactants for Industrial Applications. Biotechnol. Adv. 2011, 29, 913-922. [CrossRef]

30. Cho, I.J.; Choi, K.R.; Lee, S.Y. Microbial Production of Fatty Acids and Derivative Chemicals. Curr. Opin. Biotechnol. 2020, 65, 129-141. [CrossRef]

31. García, M.; Urrea, J.L.; Collado, S.; Oulego, P.; Díaz, M. Protein Recovery from Solubilized Sludge by Hydrothermal Treatments. Waste Manag. 2017, 67, 278-287. [CrossRef] [PubMed]

32. Hwang, J.; Zhang, L.; Seo, S.; Lee, Y.-W.; Jahng, D. Protein Recovery from Excess Sludge for Its Use as Animal Feed. Bioresour. Technol. 2008, 99, 8949-8954. [CrossRef] [PubMed]

33. Pervaiz, M.; Sain, M. Protein Extraction from Secondary Sludge of Paper Mill Wastewater and its Utilisation as a Wood Adhesive. BioResources 2011, 6, 961-970.

34. Wei, L.; Wang, K.; Kong, X.; Liu, G.; Cui, S.; Zhao, Q.; Cui, F. Application of Ultra-Sonication, Acid Precipitation and Membrane Filtration for Co-Recovery of Protein and Humic Acid from Sewage Sludge. Front. Environ. Sci. Eng. 2016, 10, 327-335. [CrossRef]

35. Devlin, H.R.; Harris, I.J. Mechanism of the Oxidation of Aqueous Phenol with Dissolved Oxygen. Ind. Eng. Chem. Fund. 1984, 23, 387-392. [CrossRef]

36. Zhang, Y.; Zhang, S.; Li, H.; Wang, C.; Jiang, F.; Lyu, J. Treatment of Municipal Sludge by Hydrothermal Oxidation Process with H2O2. Chemosphere 2020, 257, 127140. [CrossRef]

37. Khan, M.A.; Ngo, H.H.; Guo, W.S.; Liu, Y.; Nghiem, L.D.; Hai, F.I.; Deng, L.J.; Wang, J.; Wu, Y. Optimization of Process Parameters for Production of Volatile Fatty Acid, Biohydrogen and Methane from Anaerobic Digestion. Bioresour. Technol. 2016, 219, 738-748. [CrossRef] [PubMed]

38. Li, Y.; Chen, Y.; Wu, J. Enhancement of Methane Production in Anaerobic Digestion Process: A Review. Appl. Energy 2019, 240, 120-137. [CrossRef]

39. Albuquerque, M.G.E.; Concas, S.; Bengtsson, S.; Reis, M.A.M. Mixed Culture Polyhydroxyalkanoates Production from Sugar Molasses: The Use of a 2-Stage CSTR System for Culture Selection. Bioresour. Technol. 2010, 101, 7112-7122. [CrossRef] [PubMed]

40. Cho, H.U.; Park, J.M. Biodiesel Production by Various Oleaginous Microorganisms from Organic Wastes. Bioresour. Technol. 2018, 256, 502-508. [CrossRef] [PubMed]

41. Wang, X.; Carvalho, G.; Reis, M.A.M.; Oehmen, A. Metabolic Modeling of the Substrate Competition among Multiple VFAs for PHA Production by Mixed Microbial Cultures. J. Biotechnol. 2018, 280, 62-69. [CrossRef]

42. Bougrier, C.; Delgenès, J.P.; Carrère, H. Effects of Thermal Treatments on Five Different Waste Activated Sludge Samples Solubilisation, Physical Properties and Anaerobic Digestion. Chem. Eng. J. 2008, 139, 236-244. [CrossRef]

43. Urrea, J.L.; García, M.; Collado, S.; Oulego, P.; Díaz, M. Sludge Hydrothermal Treatments. Oxidising Atmosphere Effects on Biopolymers and Physical Properties. J. Environ. Manag. 2018, 206, 284-290. [CrossRef] [PubMed]

44. Xue, Y.; Liu, H.; Chen, S.; Dichtl, N.; Dai, X.; Li, N. Effects of Thermal Hydrolysis on Organic Matter Solubilization and Anaerobic Digestion of High Solid Sludge. Chem. Eng. J. 2015, 264, 174-180. [CrossRef]

45. García, M.; Collado, S.; Oulego, P.; Díaz, M. The Wet Oxidation of Aqueous Humic Acids. J. Hazard. Mater. 2020, $396,122402$. [CrossRef]

46. Liang, T.; Elmaadawy, K.; Liu, B.; Hu, J.; Hou, H.; Yang, J. Anaerobic Fermentation of Waste Activated Sludge for Volatile Fatty Acid Production: Recent Updates of Pretreatment Methods and the Potential Effect of Humic and Nutrients Substances. Process. Saf. Environ. Prot. 2021, 145, 321-339. [CrossRef]

47. Bozkurt, Y.C.; Apul, O.G. Critical Review for Microwave Pretreatment of Waste-Activated Sludge Prior to Anaerobic Digestion. Curr. Opin. Environ. Sci. Health 2020, 14, 1-9. [CrossRef]

48. Elalami, D.; Carrere, H.; Monlau, F.; Abdelouahdi, K.; Oukarroum, A.; Barakat, A. Pretreatment and Co-Digestion of Wastewater Sludge for Biogas Production: Recent Research Advances and Trends. Renew. Sustain. Energy Rev. 2019, 114, 109287. [CrossRef]

49. Fu, Q.; Wang, D.; Li, X.; Yang, Q.; Xu, Q.; Ni, B.-J.; Wang, Q.; Liu, X. Towards Hydrogen Production from Waste Activated Sludge: Principles, Challenges and Perspectives. Renew. Sustain. Energy Rev. 2021, 135, 110283. [CrossRef]

50. Liu, Y.; Lin, R.; Man, Y.; Ren, J. Recent Developments of Hydrogen Production from Sewage Sludge by Biological and Thermochemical Process. Int. J. Hydrogen Energy 2019, 44, 19676-19697. [CrossRef]

51. Wong, Y.M.; Wu, T.Y.; Juan, J.C. A Review of Sustainable Hydrogen Production Using Seed Sludge via Dark Fermentation. Renew. Sustain. Energy Rev. 2014, 34, 471-482. [CrossRef]

52. Aghapour Aktij, S.; Zirehpour, A.; Mollahosseini, A.; Taherzadeh, M.J.; Tiraferri, A.; Rahimpour, A. Feasibility of Membrane Processes for the Recovery and Purification of Bio-Based Volatile Fatty Acids: A Comprehensive Review. J. Ind. Eng. Chem. 2020, 81, 24-40. [CrossRef]

53. Bhatia, S.K.; Yang, Y.-H. Microbial Production of Volatile Fatty Acids: Current Status and Future Perspectives. Rev. Environ. Sci Biotechnol 2017, 16, 327-345. [CrossRef]

54. Bhatt, A.H.; Ren, Z.; Tao, L. Value Proposition of Untapped Wet Wastes: Carboxylic Acid Production through Anaerobic Digestion. iScience 2020, 23, 101221. [CrossRef]

55. Lee, W.S.; Chua, A.S.M.; Yeoh, H.K.; Ngoh, G.C. A Review of the Production and Applications of Waste-Derived Volatile Fatty Acids. Chem. Eng. J. 2014, 235, 83-99. [CrossRef] 
56. Patel, A.; Sarkar, O.; Rova, U.; Christakopoulos, P.; Matsakas, L. Valorization of Volatile Fatty Acids Derived from Low-Cost Organic Waste for Lipogenesis in Oleaginous Microorganisms-A Review. Bioresour. Technol. 2020, 124457. [CrossRef]

57. Elginoz, N.A.; Atasoy, M.; Finnveden, G.; Cetecioglu, Z. Ex-ante life cycle assessment of volatile fatty acid production from dairy wastewater. J. Clean. Prod. 2020, 269, 122267. [CrossRef]

58. Dahiya, S.B.; Lakshminarayanan, S.; Mohan, S.V. Steering acidogenesis towards selective propionic acid production using co-factors and evaluating environmental sustainability. Chem. Eng. J. 2020, 379, 122135. [CrossRef]

59. Fang, W.; Zhang, X.; Zhang, P.; Wan, J.; Guo, H.; Ghasimi, D.S.M.; Morera, X.C.; Zhang, T. Overview of Key Operation Factors and Strategies for Improving Fermentative Volatile Fatty Acid Production and Product Regulation from Sewage Sludge. J. Environ. Sci. 2020, 87, 93-111. [CrossRef] [PubMed]

60. Luo, K.; Pang, Y.; Yang, Q.; Wang, D.; Li, X.; Lei, M.; Huang, Q. A Critical Review of Volatile Fatty Acids Produced from Waste Activated Sludge: Enhanced Strategies and Its Applications. Environ. Sci. Pollut. Res. 2019, 26, 13984-13998. [CrossRef]

61. Yuan, Y.; Hu, X.; Chen, H.; Zhou, Y.; Zhou, Y.; Wang, D. Advances in Enhanced Volatile Fatty Acid Production from Anaerobic Fermentation of Waste Activated Sludge. Sci. Total Environ. 2019, 694, 133741. [CrossRef] [PubMed]

62. Li, X.; Liu, G.; Liu, S.; Ma, K.; Meng, L. The Relationship between Volatile Fatty Acids Accumulation and Microbial Community Succession Triggered by Excess Sludge Alkaline Fermentation. J. Environ. Manag. 2018, 223, 85-91. [CrossRef] [PubMed]

63. Ma, S.; Hu, H.; Wang, J.; Liao, K.; Ma, H.; Ren, H. The Characterization of Dissolved Organic Matter in Alkaline Fermentation of Sewage Sludge with Different PH for Volatile Fatty Acids Production. Water Res. 2019, 164, 114924. [CrossRef] [PubMed]

64. Yan, W.; Chen, Y.; Shen, N.; Wang, G.; Wan, J.; Huang, J. The Influence of a Stepwise PH Increase on Volatile Fatty Acids Production and Phosphorus Release during Al-Waste Activated Sludge Fermentation. Bioresour. Technol. 2021, 320, 124276. [CrossRef] [PubMed]

65. Chen, Y.; Ruhyadi, R.; Huang, J.; Yan, W.; Wang, G.; Shen, N.; Hanggoro, W. A Novel Strategy for Improving Volatile Fatty Acid Purity, Phosphorus Removal Efficiency, and Fermented Sludge Dewaterability during Waste Activated Sludge Fermentation. Waste Manag. 2021, 119, 195-201. [CrossRef]

66. Iglesias-Iglesias, R.; Campanaro, S.; Treu, L.; Kennes, C.; Veiga, M.C. Valorization of Sewage Sludge for Volatile Fatty Acids Production and Role of Microbiome on Acidogenic Fermentation. Bioresour. Technol. 2019, 291, 121817. [CrossRef]

67. Pang, H.; He, J.; Ma, Y.; Pan, X.; Zheng, Y.; Yu, H.; Yan, Z.; Nan, J. Enhancing Volatile Fatty Acids Production from Waste Activated Sludge by a Novel Cation-Exchange Resin Assistant Strategy. J. Clean. Prod. 2021, 278, 123236. [CrossRef]

68. Jiang, X.; Qin, Z.; Feng, L.; Chen, Y.; Chen, J.; Zhang, X.; Zhang, Z.; Guo, Y.; Sun, J. Volatile Fatty Acids Production from Waste Activated Sludge during Anaerobic Fermentation: The Effect of Superfine Sand. Bioresour. Technol. 2021, 319, 124249. [CrossRef]

69. Luo, J.; Wu, L.; Feng, Q.; Fang, F.; Cao, J.; Zhang, Q.; Su, Y. Synergistic Effects of Iron and Persulfate on the Efficient Production of Volatile Fatty Acids from Waste Activated Sludge: Understanding the Roles of Bioavailable Substrates, Microbial Community \& Activities, and Environmental Factors. Biochem. Eng. J. 2019, 141, 71-79. [CrossRef]

70. Luo, J.; Huang, W.; Zhu, Y.; Guo, W.; Yibing, L.; Wu, L.; Zhang, Q.; Wu, Y.; Fang, F.; Cao, J. Influences of Different Iron Forms Activated Peroxydisulfate on Volatile Fatty Acids Production during Waste Activated Sludge Anaerobic Fermentation. Sci. Total Environ. 2020, 705, 135878. [CrossRef]

71. Xin, X.; She, Y.; Hong, J. Insights into Microbial Interaction Profiles Contributing to Volatile Fatty Acids Production via Acidogenic Fermentation of Waste Activated Sludge Assisted by Calcium Oxide Pretreatment. Bioresour. Technol. 2021, 320, 124287. [CrossRef] [PubMed]

72. Wan, J.; Fang, W.; Zhang, T.; Wen, G. Enhancement of Fermentative Volatile Fatty Acids Production from Waste Activated Sludge by Combining Sodium Dodecylbenzene Sulfonate and Low-Thermal Pretreatment. Bioresour. Technol. 2020, $308,123291$. [CrossRef] [PubMed]

73. Inoue, Y.; Sano, F.; Nakamura, K.; Yoshie, N.; Saito, Y.; Satoh, H.; Mino, T.; Matsuo, T.; Doi, Y. Microstructure of Copoly(3Hydroxyalkanoates) Produced in the Anaerobic-Aerobic Activated Sludge Process. Polym. Int. 1996, 39, 183-189. [CrossRef]

74. Bernard, M. Industrial Potential of Polyhydroxyalkanoate Bioplastic: A Brief Review. USURJ Univ. Sask. Undergrad. Res. J. 2014, 1. [CrossRef]

75. Reddy, C.S.K.; Ghai, R.; Kalia, V.C. Polyhydroxyalkanoates: An Overview. Bioresour. Technol. 2003, 87, 137-146. [CrossRef]

76. El-malek, F.A.; Khairy, H.; Farag, A.; Omar, S. The Sustainability of Microbial Bioplastics, Production and Applications. Int. J. Biol. Macromol. 2020, 157, 319-328. [CrossRef] [PubMed]

77. Kumar, G.; Ponnusamy, V.K.; Bhosale, R.R.; Shobana, S.; Yoon, J.-J.; Bhatia, S.K.; Rajesh Banu, J.; Kim, S.-H. A Review on the Conversion of Volatile Fatty Acids to Polyhydroxyalkanoates Using Dark Fermentative Effluents from Hydrogen Production. Bioresour. Technol. 2019, 287, 121427. [CrossRef] [PubMed]

78. Tarrahi, R.; Fathi, Z.; Seydibeyoğlu, M.Ö.; Doustkhah, E.; Khataee, A. Polyhydroxyalkanoates (PHA): From Production to Nanoarchitecture. Int. J. Biol. Macromol. 2020, 146, 596-619. [CrossRef] [PubMed]

79. Zhang, J.; Shishatskaya, E.I.; Volova, T.G.; da Silva, L.F.; Chen, G.-Q. Polyhydroxyalkanoates (PHA) for Therapeutic Applications. Mater. Sci. Eng. C 2018, 86, 144-150. [CrossRef]

80. Tan, D.; Wang, Y.; Tong, Y.; Chen, G.Q. Grand Challenges for Industrializing Polyhydroxyalkanoates (PHAs). Trends Biotechnol. 2021. [CrossRef] 
81. Baybutt, P. On the completeness of scenario identification in process hazard analysis (PHA). J. Loss Prev. Process. Ind. 2018, 55, 492-499. [CrossRef]

82. Satoh, H.; Mino, T.; Matsuo, T. PHA Production by Activated Sludge. Int. J. Biol. Macromol. 1999, 25, 105-109. [CrossRef]

83. Saito, Y.; Soejima, T.; Tomozawa, T.; Doi, Y.; Kiya, F. Production of biodegradable plastics from volatile fatty acids using activated sludge. Doboku Gakkai Ronbunshu 1995, 1995, 145-154. [CrossRef]

84. Ueno, T.; Sato, H.; Mino, T.; Matsuo, T. Production of Biodegradable Plastics. Polym Prepr. Jpn 1993, 42, $3673-3675$.

85. Jia, Q.; Xiong, H.; Wang, H.; Shi, H.; Sheng, X.; Sun, R.; Chen, G. Production of Polyhydroxyalkanoates (PHA) by Bacterial Consortium from Excess Sludge Fermentation Liquid at Laboratory and Pilot Scales. Bioresour. Technol. 2014, 171, 159-167. [CrossRef] [PubMed]

86. Liu, Y.; Guo, L.; Liao, Q.; Ran, Y.; Hu, F.; Gao, M.; She, Z.; Zhao, Y.; Jin, C.; Liu, Y.; et al. Polyhydroxyalkanoate (PHA) Production with Acid or Alkali Pretreated Sludge Acidogenic Liquid as Carbon Source: Substrate Metabolism and Monomer Composition. Process. Saf. Environ. Prot. 2020, 142, 156-164. [CrossRef]

87. Al Battashi, H.; Al-Kindi, S.; Gupta, V.K.; Sivakumar, N. Polyhydroxyalkanoate (PHA) Production Using Volatile Fatty Acids Derived from the Anaerobic Digestion of Waste Paper. J. Polym. Environ. 2020. [CrossRef]

88. Suresh Kumar, M.; Mudliar, S.N.; Reddy, K.M.K.; Chakrabarti, T. Production of Biodegradable Plastics from Activated Sludge Generated from a Food Processing Industrial Wastewater Treatment Plant. Bioresour. Technol. 2004, 95, 327-330. [CrossRef] [PubMed]

89. Jiang, Y.; Hebly, M.; Kleerebezem, R.; Muyzer, G.; van Loosdrecht, M.C.M. Metabolic Modeling of Mixed Substrate Uptake for Polyhydroxyalkanoate (PHA) Production. Water Res. 2011, 45, 1309-1321. [CrossRef]

90. Morgan-Sagastume, F.; Hjort, M.; Cirne, D.; Gérardin, F.; Lacroix, S.; Gaval, G.; Karabegovic, L.; Alexandersson, T.; Johansson, P.; Karlsson, A.; et al. Integrated Production of Polyhydroxyalkanoates (PHAs) with Municipal Wastewater and Sludge Treatment at Pilot Scale. Bioresour. Technol. 2015, 181, 78-89. [CrossRef]

91. Mengmeng, C.; Hong, C.; Qingliang, Z.; Shirley, S.N.; Jie, R. Optimal Production of Polyhydroxyalkanoates (PHA) in Activated Sludge Fed by Volatile Fatty Acids (VFAs) Generated from Alkaline Excess Sludge Fermentation. Bioresour. Technol. 2009, 100, 1399-1405. [CrossRef]

92. Xu, J.; Li, X.; Gan, L.; Li, X. Fermentation Liquor of CaO2 Treated Chemically Enhanced Primary Sedimentation (CEPS) Sludge for Bioplastic Biosynthesis. Sci. Total Environ. 2018, 644, 547-555. [CrossRef]

93. Liao, Q.; Guo, L.; Ran, Y.; Gao, M.; She, Z.; Zhao, Y.; Liu, Y. Optimization of Polyhydroxyalkanoates (PHA) Synthesis with Heat Pretreated Waste Sludge. Waste Manag. 2018, 82, 15-25. [CrossRef] [PubMed]

94. Wijeyekoon, S.; Carere, C.R.; West, M.; Nath, S.; Gapes, D. Mixed Culture Polyhydroxyalkanoate (PHA) Synthesis from Nutrient Rich Wet Oxidation Liquors. Water Res. 2018, 140, 1-11. [CrossRef] [PubMed]

95. Morgan-Sagastume, F.; Karlsson, A.; Johansson, P.; Pratt, S.; Boon, N.; Lant, P.; Werker, A. Production of Polyhydroxyalkanoates in Open, Mixed Cultures from a Waste Sludge Stream Containing High Levels of Soluble Organics, Nitrogen and Phosphorus. Water Res. 2010, 44, 5196-5211. [CrossRef] [PubMed]

96. Kepp, U.; Machenbach, I.; Weisz, N.; Solheim, O.E. Enhanced Stabilisation of Sewage Sludge through Thermal Hydrolysis-Three Years of Experience with Full Scale Plant. Water Sci. Technol. 2000, 42, 89-96. [CrossRef]

97. Zhang, D.; Jiang, H.; Chang, J.; Sun, J.; Tu, W.; Wang, H. Effect of Thermal Hydrolysis Pretreatment on Volatile Fatty Acids Production in Sludge Acidification and Subsequent Polyhydroxyalkanoates Production. Bioresour. Technol. 2019, 279, 92-100. [CrossRef] [PubMed]

98. Martín, C.; Klinke, H.B.; Thomsen, A.B. Wet Oxidation as a Pretreatment Method for Enhancing the Enzymatic Convertibility of Sugarcane Bagasse. Enzym. Microb. Technol. 2007, 40, 426-432. [CrossRef]

99. Kumar, C.G.; Parrack, P. Arrowroot (Marantha Arundinacea) Starch as a New Low-Cost Substrate for Alkaline Protease Production. World J. Microbiol. Biotechnol. 2003, 19, 757-762. [CrossRef]

100. Razzaq, A.; Shamsi, S.; Ali, A.; Ali, Q.; Sajjad, M.; Malik, A.; Ashraf, M. Microbial Proteases Applications. Front. Bioeng. Biotechnol. 2019, 7. [CrossRef]

101. Rodríguez Couto, S.; Toca Herrera, J.L. Industrial and Biotechnological Applications of Laccases: A Review. Biotechnol. Adv. 2006, 24, 500-513. [CrossRef]

102. Chen, Y.; Jiang, S.; Yuan, H.; Zhou, Q.; Gu, G. Hydrolysis and Acidification of Waste Activated Sludge at Different PHs. Water Res. 2007, 41, 683-689. [CrossRef]

103. Sharma, K.M.; Kumar, R.; Panwar, S.; Kumar, A. Microbial Alkaline Proteases: Optimization of Production Parameters and Their Properties. J. Genet. Eng. Biotechnol. 2017, 15, 115-126. [CrossRef] [PubMed]

104. Gu, Y.; Xu, X.; Wu, Y.; Niu, T.; Liu, Y.; Li, J.; Du, G.; Liu, L. Advances and Prospects of Bacillus Subtilis Cellular Factories: From Rational Design to Industrial Applications. Metab. Eng. 2018, 50, 109-121. [CrossRef] [PubMed]

105. Longo, M.A.; Novella, I.S.; Garcia, L.A.; Diaz, M. Comparison of Bacillus Subtilis and Serratia Marcescens as Protease Producers under Different Operating Conditions. J. Biosci. Bioeng. 1999, 88, 35-40. [CrossRef]

106. Drouin, M.; Lai, C.K.; Tyagi, R.D.; Surampalli, R.Y. Bacillus Licheniformis Proteases as High Value Added Products from Fermentation of Wastewater Sludge: Pre-Treatment of Sludge to Increase the Performance of the Process. Water Sci. Technol. 2008, 57, 423-429. [CrossRef] 
107. García, M.; Collado, S.; Oulego, P.; Díaz, M. Proteases and laccases production by Bacillus licheniformis from hydrolysed sludge. J. Environ. Manag. currently pending of publication.

108. Liu, J.; Mu, T.; He, W.; He, T.; Lu, L.; Peng, K.; Huang, X. Integration of Coagulation, Acid Separation and Struvite Precipitation as Fermentation Medium Conditioning Methods to Enhance Microbial Lipid Production from Dewatered Sludge. Bioresour. Technol. Rep. 2019, 7, 100221. [CrossRef] 